OPEN ACCESS

Edited by:

Lubor Borsig,

University of Zurich, Switzerland

Reviewed by: Zuzana Keckesova, Academy of Sciences of the Czech Republic (ASCR), Czechia

Concetta Saponaro, Istituto Nazionale dei Tumori (IRCCS),

Italy

*Correspondence:

Yun Chen

cheny653@mail.sysu.edu.cn

Zhizhuang Joe Zhao

joe-zhao@ouhsc.edu

Jun Pang

pangjun2@mail.sysu.edu.cn

${ }^{\dagger}$ These authors have contributed equally to this work

Specialty section:

This article was submitted to Molecular and Cellular Oncology. a section of the journal

Frontiers in Oncology

Received: 25 August 2021 Accepted: 28 September 2021

Published: 14 October 2021

Citation:

Yu L, Guo Y, Chang Z, Zhang D, Zhang S, Pei H, Pang J, Zhao ZJ and Chen Y (2021) Bidirectional Interaction

Between Cancer Cells and

Platelets Provides Potential Strategies for Cancer Therapies.

Front. Oncol. 11:764119. doi: 10.3389/fonc.2021.764119

\section{Bidirectional Interaction Between Cancer Cells and Platelets Provides Potential Strategies for Cancer Therapies}

\author{
Liuting $\mathrm{Yu}^{1 \dagger}$, Yao Guo ${ }^{1 \dagger}$, Zhiguang Chang ${ }^{1 \dagger}$, Dengyang Zhang ${ }^{1}$, Shiqiang Zhang ${ }^{2}$, \\ Hanzhong Pei ${ }^{1}$, Jun Pang ${ }^{2 *}$, Zhizhuang Joe Zhao ${ }^{3 *}$ and Yun Chen ${ }^{1 *}$ \\ 1 Edmond H. Fischer Translational Medical Research Laboratory, Scientific Research Center, The Seventh Affiliated Hospital, \\ Sun Yat-Sen University, Shenzhen, China, ${ }^{2}$ Department of Urology, The Seventh Affiliated Hospital, Sun Yat-sen University, \\ Shenzhen, China, ${ }^{3}$ Department of Pathology, University of Oklahoma Health Sciences Center, Oklahoma City, \\ OK, United States
}

Platelets are essential components in the tumor microenvironment. For decades, clinical data have demonstrated that cancer patients have a high risk of thrombosis that is associated with adverse prognosis and decreased survival, indicating the involvement of platelets in cancer progression. Increasing evidence confirms that cancer cells are able to induce production and activation of platelets. Once activated, platelets serve as allies of cancer cells in tumor growth and metastasis. They can protect circulating tumor cells (CTCs) against the immune system and detachment-induced apoptosis while facilitating angiogenesis and tumor cell adhesion and invasion. Therefore, antiplatelet agents and platelet-based therapies should be developed for cancer treatment. Here, we discuss the mechanisms underlying the bidirectional cancer-platelet crosstalk and platelet-based therapeutic approaches.

Keywords: platelets, thrombosis, cancer cells, cancer-platelet crosstalk, cancer treatment

\section{INTRODUCTION}

Platelets are small anucleate blood cells $(2-4 \mu \mathrm{m})$ released from bone marrow megakaryocytes with a normal number ranging from $150 \times 10^{9} / \mathrm{L}$ to $350 \times 10^{9} / \mathrm{L}$ in the bloodstream. They not only play a crucial role in hemostasis and thrombosis formation but also modulate inflammatory response through interacting with granulocytes and pathogens (1). It is generally accepted that tumors behave like chronic or non-healing wounds and trigger inflammation $(2,3)$. As the first responder during chronic inflammation and cancer progression, platelets have such advantages as small size, the large numbers in the bloodstream and versatile biophysical properties including adhesion, aggregation, and streamline migration (4). Activated platelets can change their shape and release $\alpha$ granules, dense granules or lysosomal granules in response to different stimuli. These granules contain various cytokines or molecules with distinct functions (5).

Ever since Armand Trousseau described the relationship between cancer and abnormal blood coagulation in 1865 , numerous studies have showed that platelets contribute to cancer-associated 
thrombosis and influence the outcomes of cancer treatment. Cancer cells can activate platelets and cause their aggregation in the circulation, while platelets help to maintain the integrity of tumor vasculature and participate in multiple steps of metastasis (6). Hence, platelets are excellent biomarkers for liquid biopsy to improve diagnostic and prognostic accuracies (6). Furthermore, antiplatelet agents have a great potential in anti-cancer therapies $(7,8)$.

This review addresses the bidirectional interaction between platelets and cancer by highlighting facts that elevated platelet counts in patients with malignancy predict adverse prognosis and short survival and that cancer cells induce platelet production, activate platelets and alter their functions. Potential strategies for platelet-based cancer therapies are also discussed.

\section{CORRELATION BETWEEN INCREASED PLATELET COUNTS AND CANCER PROGNOSIS}

From clinical data, many cancer patients were reported to have high platelet counts. Generally, thrombocytosis is defined as more than $400 \times 10^{9} / \mathrm{L}$ of platelet counts. The frequencies of pretreatment thrombocytosis varied according to cancer types, $4.0 \%$ to $21 \%$ in gastric cancer patients $(9,10), 9.8 \%$ to $13.2 \%$ in colorectal cancer patients $(11,12)$, and $3.7 \%$ to $18.2 \%$ in breast cancer patients $(13,14)$. Increased platelet counts usually indicate worse prognosis and shorter survival in patients with malignant diseases (15-18). For example, Zhou et al. investigated 6754 ovarian cancer patients and found that elevated pretreatment platelet counts denoted poor survival outcome and unfavorable clinicopathological parameters (16). In gastric cancer, patients with thrombocytosis had worse overall survival (HR 1.57, 95\% CI 1.36-1.81) and higher likelihood of recurrence (OR, 2.28; 95\% CI, 1.55-3.35) (19). Although only $2.4 \%$ patients with oesophageal adenocarcinoma had paraneoplastic thrombocytosis, such patients had a higher rate of mortality (86\%) and lymph node metastasis $(69 \%)$ than patients with normal platelet counts ( $50 \%$ and $31 \%$, respectively). The former patients died with a median survival time of 23.2 months while the latter died with a median survival time of 76.9 months (20). These data demonstrate that platelets are likely to take an important part in progression. Interestingly, a new finding denoted that upper tract urothelial carcinoma patients with both high platelet counts and programmed cell death ligand-1 (PD-L1) positivity had shorter metastasis-free survival and overall survival, demonstrating PD-L1 expression might synergize with platelet count in modulating cancer development (21).

Thrombocytosis is significantly associated with cancer metastasis. For ovarian patients with thrombosis before surgery, anticoagulant drugs was used to inhibit the thrombosis formation and cancer metastasis (22). Latest data from patients who had undergone radical hysterectomy and pelvic lymphadenectomy showed that thrombocytosis could be one predictor of pelvic lymphatic metastasis in the early squamous cervical cancer (23). In addition, platelet counts correlated with tumor invasion and distant metastasis in gastric cancer (24), colorectal cancer $(17,25)$ and pulmonary malignancy (26). Thus, platelets seem to actively participate in cancer dissemination, which may be a main reason for adverse prognosis in cancer patients with thrombocytosis.

Different researchers set the cutoff values of thrombocytosis varying from 270 to $450 \times 10^{9} / \mathrm{L}$ in their studies. This discordance may lead to between-study heterogeneity and affect the significance of results (16). For example, Shimada (27) and Ling (28) defined thrombocytosis as platelet count over $293 \times 10^{9} / \mathrm{L}$ in esophagus tumor. They found thrombocytosis appeared in approximately $20 \%$ patients, whereas Aminian (29) and Dutta (30) reported a $3.4-4.46 \%$ incidence based on the $400 \times 10^{9} / \mathrm{L}$ cutoff. In fact, it may be useful to adopt specific cut-off values according to the features of tumors. For instance, lower cutoff for platelet counts $\left(300 \times 10^{9} / \mathrm{L}\right)$ was more informative to predict prognostics of inflammatory breast cancer (31). Moreover, a cohort study demonstrated that the risk of cancer in men with a platelet count over $325 \times 10^{9} / \mathrm{L}$ exceeded $3 \%$ while the risk in women with a platelet count over $375 \times 10^{9} / \mathrm{L}$ exceeded $2.8 \%$. This finding could be a cue for earlier diagnosis of cancer in patients with platelet counts above these values (32). Since platelet counts were also affected by age and sex $(33,34)$, age/sex-specific ranges of platelet counts were introduced to better predict the risk of total mortality (35). More data will help to define a clear relationship between the platelet counts and the cancer incidence. Furthermore, using platelet counts as indicators for diagnosis and prognosis should take account of patient conditions.

Altogether, elevated platelet counts can be recognized as a risk marker in certain types of cancers $(16,17,36)$. However, it was found that platelet count was not statistically significantly associated with colorectal cancer patient survival though higher platelet counts were observed in higher tumor stage (37). Ishibashi et al. also suggested that platelet count was nonindependent prognostic factors for overall survival in esophageal squamous cell carcinoma (38). Studies showed that a combination of platelet counts and other factors often has higher prediction value than a single index, such as plateletto-lymphocyte ratio (PLR) (39-41) and hemoglobin/albumin/ lymphocyte/platelet (HALP) levels (42). Aside from neutrophillymphocyte ratio (NLR) and lymphocyte-monocyte ratio (LMR), patients with high PLR were at higher risk of distant metastases and worse prognoses in renal cell cancer (43), cervical cancer (44), bladder cancer (45), colorectal adenocarcinoma (46), head and neck squamous cell carcinoma (47), and gastric cancer (48). Recently, a novel parameter neutrophil/platelet/ lymphocyte/differentiation score (NPLDS) has been introduced to accurately predict the prognosis of chemotherapeutic response in advanced gastric cancer (49). Collectively, the detection of PLR, HALP, and NPLDS is valuable in the evaluation of cancer patient outcomes while the underlining mechanisms need further investigation. 


\section{IMPACTS OF CANCER ON PLATELETS}

Clinical data demonstrated that cancer patients had a higher risk of venous thrombosis than the healthy individuals do (50). Thrombosis has been reported to be the second leading cause of malignancy-associated death (51). Recently, the relationship between thrombosis and cancer reviewed by Plantureux et al. indicated that cancer cell-induced platelet production, activation and function alteration might be the major reasons of thrombosis (5). Zhang et al. have found that activated platelets from patients with colorectal cancer could stimulate the formation of neutrophil extracellular traps (NETs) and ultimately enhance procoagulant activity (52). Cancer cellplatelet interaction incited platelet-derived extracellular vesicles (EVs) release and fibrin formation, thus inducing thrombus formation under shear flow (53).

\subsection{Platelet Production}

Cancer cells can induce platelet production. Early studies showed that overexpression of interleukin-1 $\beta$ (IL-1 $\beta$ ) (54) and interleukin-6 (IL-6) in malignant diseases $(55,56)$ was related to thrombocytosis. In subsequent studies, thrombocytosis was found to be caused by IL-6 in Granulocyte-Colony-Stimulating Factor (G-CSF)-producing tumors and by both granulocyte-CSF and IL-6 in Granulocyte Macrophage-Colony-Stimulating Factor (GM-CSF)-producing tumors (57). Studies have shown that tumors are able to produce thrombopoietin (TPO) (58) and IL-6 (59). TPO is the primary regulator of megakaryocyte progenitor differentiation and platelet production (60), while IL-6-induced thrombopoiesis was dependent on TPO (61). In tumor-bearing mice, treatment with IL-6 antibody abrogated thrombocytosis and augmented the therapeutic efficacy of paclitaxel (59). Knock out of IL-6 decreased the platelet counts and reduced tumor burden in a colitis-associated cancer model (62). It was noteworthy that the demand for platelets modulated murine TPO mRNA levels at least in part (63). Recently, Hill et al. suggested that tumor-derived soluble factors potentially deregulated autophagy in hematopoietic progenitors and megakaryocytes and subsequently promoted megakaryopoiesis and thrombopoiesis (64). Nonetheless, the precise molecular pathway of cancer cell-induced platelet production is yet to be defined.

\subsection{Platelet Transcriptome and Proteome Alteration}

Studies indicated that platelets from cancer patients altered their growth factor contents (65-67), RNA profile (68-71) and other parameters including platelet counts, volumes, and protein contents (72) in early stage.

\subsubsection{Transcriptome Alteration}

It was reported that 197 platelet-related genes were significantly down-regulated in metastatic lung cancer, implying that functions of platelets may alter during cancer metastasis (70). Later, Best et al. found that mRNA sequencing of tumoreducated platelets (TEPs) was capable of distinguishing cancer patients from healthy individuals with $96 \%$ accuracy and providing the location information for six major tumors (nonsmall cell lung cancer, glioblastoma, colorectal cancer, pancreatic cancer, breast cancer and hepatobiliary cancer) with $71 \%$ accuracy. Moreover, TEP mRNA profiles could identify MET or HER2-positive and mutant KRAS, EGFR or PIK3CA tumors as well (68). Zhang et al. revealed that in non-small cell lung cancer (NSCLC) patients, expression levels of over 2000 platelet mRNAs and ncRNAs were changed. Some up-regulated genes including PPBP, OST4, PF4, GP1BB and CCL5 were related to tumor progression. Worthy of note, histological types and tumor stages could influence the gene expression (73). Analogously, integrated bioinformatical analysis also identified twenty differentially expressed TEP mRNAs in NSCLC patients, which were associated with transport process, localization and catalyticactivity (69). Moreover, TEP mRNAs were found be associated with chemotherapeutic effects (74). Together, RNA transcriptome mapping established TEPs as promising biomarker source in liquid biopsies (75-77). Recently, Best et al. have provided a protocols to combine platelet RNA sequencing and swarm intelligence-enhanced classification algorithm development for disease diagnostics (78).

It is not quite clear how tumor cells changed TEP RNAs. One scenario is that blood platelets may take up tumor-derived microvesicles which contain numerous RNA and proteins. These microvesicles are able to promote tumor growth, angiogenesis and immune evasion (79-81). This hypothesis is supported by the fact that Glioma RNA marker EGFRvIII and prostate cancer RNA marker PCA3 were detected in patient platelets (82). It will be interesting to know how tumor-derived RNAs change platelet functions and foster tumor progression.

\subsubsection{Proteome Alteration}

Platelets contain a wide range of proteins including chemokines, cytokines, proteases and growth factors, which are synthesized by megakaryocytes or taken up from the blood by megakaryocytes and circulating platelets $(65,72,83,84)$. Protein content in platelets was notably influenced in the presence of cancer. For example, concentrations of vascular endothelial growth factor (VEGF), platelet-derived growth factor (PDGF), platelet factor 4 (PF4) (66), connective tissueactivating peptide III (CTAPIII) and thrombospondin-1 (TSP-1) in platelets were altered depending on the types of cancer $(67,72$, $85,86)$. Sabrkhany et al. analyzed the platelet proteome of patients with early-stage lung and pancreas cancers. It turned out that 85 of 4384 unique proteins in platelets significantly changed their expression in cancer patients. Interestingly, 81 of these 85 proteins restored their normal level after tumor resection. Most of the over-expressed proteins were involved in inflammation, immune response, cytoskeleton organization and transport while most down-regulated proteins were linked to antigen presentation/processing and protein proteolysis. On the whole, platelet proteome was remarkably altered in cancer patients with malignant disease or early-stage and localized disease, showing that the proteome could serve as a potential cancer biomarker $(87,88)$. By far, a group of platelet protein biomarkers have been identified for differentiating benign adnexal lesions and ovarian cancer (FIGO stages III-IV) with 
high sensitivity and specificity (89). Some proteins like ACTN4 (90), WDR1 (91) and TLN1 (92) were increased while other proteins (such as $\mathrm{PHB}$ and SRPB6) were decreased in ovarian cancer (89). However, how tumor cells modify platelet proteome still remains unclear so far. It is possible that the megakaryocytes (93) and circulating platelets (65) both absorb proteins originated from tumor cells and therefore increase certain protein content. Some platelet proteins like ATP6Ap1 are down-regulated presumably due to the autoantibodies generated in cancer patients $(87,94)$. In addition, megakaryocyte functions can also be influenced by cancer cells, which consequently affect platelet content (59). Taken together, the platelet transcriptome and proteome in cancer patients are both profoundly altered. These alterations may provide valuable clues for early diagnosis of cancer. Meanwhile, the role of TEP RNAs and proteins in platelet functions also warrant further studies.

\subsection{Platelet Activation}

In the bloodstream, cancer cells perturb the surrounding microenvironment and induce abnormal platelet responses through direct cell contact or by releasing various mediators. Such mediators include $\operatorname{ADP}(95,96)$, thromboxane A2 $\left(\mathrm{TXA}_{2}\right)$ (97), tissue factor (TF) (98), thrombin (99) and matrix metalloproteinases (MMPs) (100-102). Moreover, cancer cells could directly facilitate platelet secretion of dense-granules, which was required for cancer cell-induced platelet aggregation (103). Of note, inflammatory cytokines such as TNF $\alpha$, IL-6, and IL-8 and platelet agonists such as thrombin and ADP in the tumor microenvironment could promote platelet autophagy and then activate platelets, leading to thrombosis and cancer metastasis (64).

The expression level of TF was raised in many types of cancers, which was strongly associated with high incidence of thrombotic events (104-106). TF on the cancer cell surface and tumor-derived microparticles could trigger extrinsic coagulation cascade and platelet activation $(53,98)$. Apart from the TFdependent mechanism, breast cancer cell-secreted extracellular vesicles could foster platelet activation, aggregation and plasma coagulation in a TF-independent manner (107). Experimental data showed that platelets could in turn facilitate TF expression and coagulating function in ovarian cancer (108).

High-mobility group box1 (HMGB1) released from tumor cells is an endogenous ligand of platelet toll-like receptor 4 (TLR4). The interplay between HMGB1 and TLR4 contributed to platelet activation and tumor spreading in mice bearing with melanoma and Lewis lung carcinoma (109).

CD97, a common tumor-associated antigen predominantly expressed in hematopoietic cells (110) and several primary and metastatic tumors (110-112), was found to be able to activate platelets and foster tumor cell invasion and metastasis via the LPA-mediated signal pathway (113). Ward et al. demonstrated that CD97-platelet interaction promoted platelet granule secretion, disrupted endothelial cell tight junction and further facilitated transendothelial migration (113).

Interestingly, cancer cells are capable of producing immunoglobulin $\mathrm{G}$ ( $\mathrm{IgG}$ ) that is quite different from B lymphocyte-derived IgG (114-116) and is reported to promote tumor growth and metastasis $(117,118)$. Of late, Miao et al. demonstrated that cancer cell-derived IgG could bind to platelet Fc $\gamma$ RIIa, initiate Fc $\gamma$ RIIa-signaling pathway and mediate platelet activation and that knocking down of IgG significantly reduced CD62P expression, aggregation, and ATP release of platelets (119).

In addition, cancer cells could induce platelet aggregation and thrombus by directly binding via their cell surface podoplanin (PDPN) to C-type lectin receptor type 2 (CLEC-2) on the platelets (120-122). In breast cancer and melanoma, direct interaction between cancer cells and platelets induced platelet activation, modulated the VEGF release, and regulated CXCL5 and CXCL7 discharge from platelet granules (123), which were required for granulocytes recruitment and "early metastatic niches" formation (124).

Cancer cells can indirectly activate platelets in tumor microenvironment (125). Recent studies have highlighted the involvement of neutrophil extracellular traps (NETs) in cancerassociated thrombosis (126). NETs are composed of DNA, histones, and antimicrobial proteins. Tumor-derived G-CSF promoted the blood neutrophil production and NETs formation, which led to platelet activation and thrombosis (127). Pancreatic cancer cells were reported to stimulate the generation of NETs via soluble protein mediators and induce platelet adhesion and active status (128). Extracellular histones could accelerate procoagulant phenotype of platelets (phosphatidylserine exposure, FV expression, P-selectin translocation) and facilitate thrombin generation via activating platelets (129). In addition to neutrophils, monocytes/ macrophages can also generate extracellular traps in response to several stimuli (130) while whether cancer cells modulate monocytes/macrophages for platelet activation still remains unclear. NET-associated histones can promote the von Willebrand factor (a glycoprotein important for platelet adhesion and aggregation) release of endothelial cells (131). Moreover, cancer cell-derived pro-inflammatory factors upregulated TF expression of endothelial cells and monocytes $(125,132,133)$, which could be attributed to platelet activation and thrombosis.

Collectively, overwhelming data suggest that cancer cells are capable of initiating platelet hyperactivation directly or indirectly thereby facilitating their development and metastasis.

\section{PLATELET-SUPPORTED CANCER PROGRESSION}

Tumor-educated platelets (TEPs) can serve as good allies of cancer cells in tumor growth and metastasis through various ways.

\subsection{Tumor Growth}

Platelets secreted a number of growth factors including transforming growth factor $\beta$ (TGF $\beta$ ) and PDGF to foster tumor growth (134). In murine models of orthotopic ovarian 
cancer, platelet depletion resulted in increased tumor cell apoptosis and decreased tumor weight and microvessel density (59). After coincubation with platelets, human and murine ovarian cancer cells displayed a remarkable increase in proliferation rate in a manner dependent on the interplay between platelet released TGF1 $\beta$ and tumor cell receptor TGF $\beta R 1$ (135). Deficiency of the TGF $\beta 1$ or TGF $\beta R 1$ reduced half of the tumor size of orthotopic ovarian cancer (136). Additionally, P-selectin on activated platelets mediated platelet accumulation within solid tumors such as insulinoma and malignant melanoma, and consequently, aggregated platelets released VEGF and other growth factors to accelerate tumor growth and angiogenesis (137). In vivo, VEGF was found to stimulate breast cancer cell proliferation through cooperation between VEGFR-2 and integrin signaling (138). These results have confirmed the positive impacts of platelet-produced growth factors in tumor growth.

In addition to growth factors, platelet factor 4 (PF4) was found to regulate tumor microenvironment and expedite lung cancer growth (139). In addition, CLEC-2-podoplanin interaction could also modulate the proliferation of lung squamous cell carcinoma (140). Moreover, interaction between $\mathrm{ADP}$ and its receptor $\mathrm{P}_{2} \mathrm{Y}_{12}$ on platelets played a significant role in ovarian cancer cell proliferation. Use of $\mathrm{P}_{2} \mathrm{Y}_{12}$ antagonist could suppress primary tumor growth in the presence of platelets $(141,142)$. Taken together, highly activated platelets can greatly promote tumor growth via multiple pathways.

\subsection{Cancer Metastasis}

Studies have showed that about $90 \%$ of human cancer-related death is due to cancer metastasis (143). Cancer metastasis consists of an invasion-metastasis cascade, namely, tumor cells firstly exit their primary growth sites, survive in the circulation, extravasate at distant organ site, and lastly proliferate in the foreign microenvironments (144). Tumor cell-educated platelet (TEPs) participated in multiple steps of metastasis, helping the "villain" to do evil $(134,145)$. Blocking platelet activation (146) or in the absence of platelets (147), cancer metastasis was markedly repressed.

\subsubsection{Invasion and EMT}

Platelet surface molecules (e.g. P-selectin, GPIb $\alpha, \alpha \operatorname{IIb} \beta_{3}$ ) and secreted factors from $\alpha$-granules (e.g. TGF $\beta$, LPA, MMPs) and dense granules (e.g. serotonin, ADP, histamine) all support cancer dissemination (148). It was reported that plateletderived exosomes and exosomal HMGB1 appeared to facilitate cancer malignancy (149). Recently, Vismara et al. showed that platelet-derived extracellular vesicles could be internalized by breast cancer cell line MDA-MB-231 and strongly potentiated cell migration and invasiveness which was associated with p38MAPK and myosin light chain (150). Intriguingly, prostate cancer stem cells (PCSCs) preferentially induced platelet aggregation, which could be attributed to increased prothrombin expression. In turn, activated platelets released stromal derived growth factor- $1 \alpha$ (SDF-1 $\alpha)$ to preferentially enhance PCSC invasion $(151,152)$.
Epithelial-mesenchymal transition (EMT) process helps cancer cells to acquire malignant cell traits including cell motility, invasiveness, and resistance to apoptosis (153). Platelets had the ability to accelerate EMT through the TGF $\beta$ signal pathway $(154,155)$. Labelle et al. showed that plateletderived TGF $\beta$ and direct platelet-tumor cell contact synergized to activate TGF $\beta /$ Smad and NF- $\kappa B$ pathways in cancer cells, consequently enhancing lung metastasis (156). A latest report denoted that tumor necrosis factor receptor-associated factor (TRAF) family member-associated NF- $\kappa B$ activator (TANK)binding kinase 1 (TBK1) acted as a mediator of platelet-induced NF- $\kappa$ B activation and EMT in mammary carcinoma cells (157). Podoplanin on tumor cells could mediate platelet aggregation via binding to CLEC2 on platelets (158) and induce TGF $\beta$ release from platelets, facilitating EMT and extravasation of tumor cells (159). Knockdown of podoplanin suppressed tumor growth and metastasis of lung squamous cell carcinoma (140). In addition to Podoplanin-CLEC2 interaction, integrin $\alpha 2 \beta 1$ contacting could induce TGF- $\beta 1 / \mathrm{pSmad} 3$ pathways as well (160). These findings confirm the importance of platelet-derived TGF $\beta$ in tumor cell aggressiveness.

Other components of platelets are also involved in the EMT process. For instance, platelet TSP1 and clusterin were able to mediate cancer cell invasiveness by regulating MMP-9 via the p38MAPK pathway (161). Additionally, through the cooperation with platelets, tumor cell integrin $\alpha \mathrm{v} \beta 3$ had the capacity to promote tumor cell extravasation and colonization in a second organ (162). Recently, researchers discovered that chemokine CCL5 and epidermal growth factor (EGF) released by platelets could increase the IL- 8 secretion of tumor cells via initiating Akt signaling (163), while platelet-secreted CCL3 engaged its receptor CCR5 on tumor cells to upregulate MMP-1 possibly via the NF- $\kappa B$ pathway. Subsequently, tumor cells elevated their invasive and migratory abilities (164).

Lysophosphatidic acid (LPA), a crucial mediator in the tumor environment, could inhibit immune response (165) and promote cancer cell invasion and metastasis (166). Platelets are the highest producer of LPA. When platelets were activated by cancer cells, Autotaxin (ATX) with lysophospholipase D activity was released from $\alpha$-granules and catalyzed the LPA generation (167). Platelet-derived LPA stimulated the secretion of IL-6 and IL- 8 (168) and enhanced osteolytic bone metastasis in breast cancer (169). Further evidence indicated that ATX/LPA-signaling axis not only facilitated tumor cell motility, survival, and proliferation (170), but also induced chemoresistance by stabilizing nuclear factor-like 2 (Nrf-2) and upregulating those genes involved in drug resistance and oxidative stress response (171). These results show that the ATX/LPA-signaling axis may be highly active during tumor progression. One may postulate that blocking this signaling axis may be therapeutically important.

\subsubsection{Adhesion}

A great number of adhesive molecules are expressed on the platelet membrane.These include integrins (e.g. aIIb $\beta 3, \alpha 6 \beta 1$, $\alpha v \beta 3), P$-selectin, glycoprotein (GP) Ib-IX-V, and the immunoglobulin superfamily (e.g. GPVI, Fc $\gamma$ RIIa, PECAM-1) $(134,172,173)$. These molecules make platelets adhere to CTCs 
as well as endothelial cells and facilitate intravasation and extravasation of CTCs $(134,174)$. Recently, Schlesinger gave a comprehensive illustration about the role of platelet receptors in tumor cell-platelet interaction (175). For example, on platelet activation, P-selectin was translocated to the platelet surface, which contributed to platelets' binding to endothelial cells, leukocytes and cancer cells (176). Then P-selectin mediated cancer cell metastasis (177), tumor growth and angiogenesis (137, 178). Platelet integrin $\alpha 6 \beta 1$ directly interacted with tumor cell ADAM9, initiating platelet activation, granule secretion and mediating tumor cell dissemination (179). Glycoprotein (GP)-VI on platelets, a key receptor for collagen, supported platelet adhesion and cancer cell arrest in the vasculature (180). It could also bind to tumor cell-expressed galectin-3. GPVI blockade in vivo prevented lung metastasis of colon and breast cancer cells (181). Platelet microparticles (PMPs) delivered platelet-derived receptors like CD41 to tumor cells and increased tumor cell adhesiveness to endothelium and fibrinogen. Transendothelial migration of tumor cells was consequently enhanced (182).

In summary, platelets enhance adhesion of CTCs via adhesive proteins thereby promoting their dissemination.

\subsubsection{Angiogenesis}

Active proliferation and metastasis of tumor cells required new blood vessels that supplied adequate nutrients, oxygen and growth factors (183), while platelets induced early and advanced stages of angiogenesis and stabilized the newly formed vessels in tumor microenvirenment $(184,185)$. Upon activation, platelets released distinct $\alpha$-granules containing angiogenic regulators such as VEGF, PDGF, PF4 and endostatin $(134,186)$. Stimulation of receptor PAR1 on platelets led to the secretion of pro-angiogenic molecules such as VEGF, whereas PAR4 stimulation contributed to the release of anti-angiogenic molecules (187). Of interest, it was found that PAR1- and PAR4-activated platelets both enhanced endothelial progenitor cells migration and tube formation, but PAR1 was more potent than PAR4 (188). Thrombin was thought to have a central role in angiogenesis (189). Thrombin/PAR1 activation could not only contribute to the upregulation of angiogenic factors, but also increase endothelial cells barrier permeability to induce angiogenesis and tumor seeding (190). VEGF, the most potent proangiogenic molecule, was significantly discharged from platelets after thrombin or TF stimulation in early breast cancer patients (191). Anticoagulants reduced VEGF release and thus weakened angiogenic potential (192). ADP-induced platelet activation resulted in increased VEGF and minimal endostatin production, suggesting that $\mathrm{ADP}$ release had proangiogenic effects in the tumor microenvironment (193).

Additionally, glycoprotein (GP) VI on the platelet surface contributed to vascular integrity within tumors. An antibody against platelet GPVI could cause tumor hemorrhage and augmented the effects of chemotherapeutic agents without systemic bleeding complications in vivo (194). PMPs that contain abundant RNA and proteins play a significant part in angiogenesis. It was reported that PMPs promoted proliferation, migration and tube formation of human umbilical vein endothelial cells, leading to angiogenesis (195). Signaling pathways of PMP-induced sprouting were involved with PI3kinase, Src kinase and ERK (196). In lung cancer, PMPs stimulated the generation of MMPs, VEGF, IL- 8 and hepatocyte growth factor (HGF), which were common angiogenic regulators for metastasis (182). All above findings highlight the importance of platelets in supporting cancerassociated angiogenesis and hence enhancing cancer metastasis.

To defend against tumor angiogenesis in the early stage, hostexpressed thrombospondin 1 (TSP1) and endostatin act as negative regulators. Human platelet-derived TSP1 was acquired from megakaryocytes and stored in $\alpha$-granules (83). It was thought to be a sensitive and stable marker to monitor platelet activation in vitro (197). In platelets of tumor-bearing mice, TSP1 was increased and thus reduced tumor growth by angiogenesis inhibition (83). However, it is unclear whether selective release of angiogenic regulators in platelets can be controlled or not. This may be a promising strategy for repressing tumor angiogenesis via inhibiting VEGF release or accelerating the release of endostatin and TSP1.

\subsubsection{TCIPA}

Platelet aggregation in response to tumor cell stimulation is known as tumor cell-induced platelet aggregation (TCIPA) (198, 199). TCIPA is able to prevent circulating tumor cells (CTCs) from high shear forces and immune surveillance. Several molecules participate in TCIPA formation, including ADP, TXA $_{2}$, MMPs and TF $(199,200)$. Previous studies indicated that cancer cells with different metastatic potentials had varying abilities to induce TCIPA (201). Zarà et al. explored the molecular pathways of TCIPA formation in breast cancer cells and colorectal cancer cells (202). They made the following discoveries: (1) Plasma was the indispensable environment for the interaction between cancer cells and platelets. (2) Cancer cells interacted with platelets and thus induced thrombin generation, leading to platelet aggregation. (3) Cancer cells regulated TCIPA mainly through binding of fibrinogen to integrin $\alpha \operatorname{IIb} \beta 3$ on activated platelets. Integrin $\alpha \operatorname{IIb} \beta 3$ outside-in signaling stimulated phospholipase C (PLC) and Raplb-GTP and subsequently expedited platelet activation. (4) TCIPA was supported by ADP and its P2Y12 receptor on platelet surface. (5) Different breast and colorectal cancer cell lines triggered platelet aggregation in the same manner, suggesting that the type and metastatic phenotype of cancer cells didn't make a striking difference in the formation of TCIPA. However, whether other types of cancer adopt the similar ways to induce TCIPA still needs to be studied.

\subsection{Immune Suppression}

CTCs surrounded by activated platelets can escape from innate immune surveillance and cause distant hematogenous metastasis (203). It is known that natural killer (NK) cells play a key role in antitumor immunity (204) while platelets are able to impair NK cell antitumor reactivity in different ways. First of all, platelets could help CTCs evade immune recognition through transferring platelet-derived MHC class I to CTCs (205). Secondly, platelets released TGF $\beta$ to downregulate 
immunoreceptor NKG2D on NK cells (206). Thirdly, ectosomes released from platelets were reported to cause NK cell disfunction by suppressing the expression of NK cell surface receptors (NKG2D, NKp30, DNAM-1) in a TGF 31 -dependent way (207). TGF $\beta 1$ in the ectosomes increased miR-183 and thus decreased DNAX activating protein $12 \mathrm{kDa}$ (DAP12), leading to the disturbance of $\mathrm{NK}$ functions and downstream signal transduction (208). Fourthly, platelet-derived TGF $\beta 1$ induced Foxp3 expression in conventional CD4+ T cells and converted them into regulatory $\mathrm{T}$ cells that were capable of killing activated T cells (209). Of note, constitutive expression of TGF $\beta$-docking receptor Glycoprotein A Repetitions Predominant (GARP) in platelets activated TGF $\beta$ and augmented the immunosuppressive effects on cancer cells. Thus, platelet inhibition can potentially reinforce adoptive T cell therapy (210). In headneck squamous cell carcinoma, platelets inhibited $\mathrm{T}$ cell proliferation, cytokine production (IFN- $\gamma$, TNF- $\alpha$ ) of CD $4+$ T Cells and decreased PD- 1 expression on CD4+ and CD8+ T cells (211). Platelet-derived PD-L1 disturbed T cell functions and promoted PD-L1 negative tumor growth (212).

A more recent study demonstrated that platelets also facilitated the release of NKG2D ligands MICA and MICB from tumor cells and modulated NKG2D expression on NK cells (213), in a process that platelet-derived ADAM10 (a member of the disintegrin and metalloproteinase family of proteins) may be involved (214). Similarly, platelets could also decrease expression of CD112 and CD155 on tumor cells as well as their associated receptors CD226 and CD96 on NK cells. As a result, tumor cells were protected from NK cell recognition and cytotoxicity (213). Immunomodulatory TNF family members, such as glucocorticoid-induced TNF receptor-related ligand (GITRL) (215), receptor activator of NF- $\mathrm{KB}$ ligand (RANKL) and Oxford 40 ligand(OX40L) were upregulated in activated platelets from cancer patients, indicating that they were possibly involved in tumor pathophysiology (216). Platelet-derived GITRL (217) and RANKL (216) both induced NK cell inhibition via interacting with their specific receptors on $\mathrm{NK}$ cells (GITR, RANK, respectively). Recently, Zhou et al. showed that GITRL overexpression of platelets was substantially associated with tumor-derived soluble factors such as TGF $\beta$ (215). These studies prove that platelets boost CTCs' survival in the process of hematogenous metastasis by suppressing innate and adaptive immunity.

\subsection{Apoptosis Resistance}

CTCs have to overcome detachment-induced apoptosis (namely anoikis) for survival in the circulation. Haemmerle et al. recently elucidated that platelets induced anoikis resistance and metastasis by activating Yes-associated protein 1 (YAP1) via the RhoA-MYPT1-PP1 axis (218). Moreover, PDGF could mediate anti-apoptotic properties of fibroblasts via the Ras/PI (3)K/Akt/IKK/NF- $\kappa B$ pathway (219). In pancreatic cancer, it was found that platelet-derived growth factor-BB enhanced anoikis resistance and cell migration through YAP signaling (220). Apoptosis signal-regulating kinase 1 (Ask1) is an upstream kinase of the stress-induced mitogen activated protein kinase (MAPKs) pathway. Deficiency of Ask1 impaired platelet granule secretion and TXA2 generation and protected mice from thrombosis (221). Furthermore, the Ask1-JNK/p38 axis also activated $\mathrm{ADP}$ receptor $\mathrm{P}_{2} \mathrm{Y}_{12}$ on platelets to augment tumor metastasis to the lung (222). Intriguingly, binding of platelet TSP1 to the calreticulin/LRP1 complex protected mouse embryo fibroblasts (MEFs) from anoikis via the PI3K/Akt signaling pathway (223). Nevertheless, it remains unknown whether platelet-produced TSP1 is involved in anoikis resistance of CTCs.

\subsection{Platelet-Related Chemoresistance}

Increasing evidence indicates that human platelets are associated with chemoresistance of cancer cells. Advanced gastric cancer patients with platelet aggregation have a higher rate of chemoresistance $(58.3 \%)$ than those without platelet aggregation (20.0\%) (224). Primary tumor cells surrounded by platelets exhibited EMT-like morphological changes and resisted some common anticancer drugs (225). It has been established that platelets promote the EMT process of cancer cells, which plays an important role in drug-resistance $(226,227)$. EMTrelated transcription factors such as Snail $(228,229)$ and Slug $(229,230)$ are involved in chemotherapy resistance. A recent study has suggested that platelet-derived ADP and ATP increased the expression level of Slug and subsequently modulate human equilibrative nucleoside transporter 1 and cytidine deaminase. As a consequence, they enhanced proliferation and survival of pancreatic ductal adenocarcinoma cells in the presence of gemcitabine (231). In NSCLC, incubation with platelets could prominently relieve the cisplatin-induced inhibition of cancer cell proliferation and angiogenesis. Platelets prevented caspase-3 activation and reduced cancer cell apoptosis through Akt/Bad/Bcl-2 signaling (232). In addition, plateletderived chemokine RANTES and TSP1 (233) both increased the survival of paclitaxel-treated cancer cells (234). Casagrande et al. suggested that platelet-secreted factors ((EGF, PDGF, TGF$\beta$, IGF and CCL5) protected cancer stem cells from paclitaxel, cisplatin and carboplatin (235). All above data prove the involvement of platelets in cancer chemoresistance. Understanding the mechanisms underlying the platelet-related chemoresistance will help to solve a major problem in anticancer drug therapy.

Radziwon-Balicka et al. tried to explain the possible reasons why platelets increase the survival of colonic and ovarian adenocarcinoma cells in the presence of 5-fluorouracil and paclitaxel (234). According to their experimental data, they surmised that platelets were capable of protecting cancer cells from anticancer drug-induced apoptosis and cell cycle inhibition. Platelets facilitated DNA repair processes and the expression of p38 and JNK-p54 MAPKs (234) that mediated proliferation, differentiation, survival and migration (236).

\section{PLATELETS IN CANCER THERAPY}

In view of the close relationship between platelets and cancer development, there are two major strategies for platelet-targeted cancer therapies. One is to develop antiplatelet drugs while the 
other is to transform the platelets themselves into drug delivery vehicles.

\subsection{Antiplatelet Agents}

Considering the important role of platelets in cancer development and dissemination, antiplatelet agents seem to be a promising adjuvant strategy for cancer treatment. At present, the most studied drug is aspirin, a cyclooxygenase 1 (COX) inhibitor. As a nonsteroidal anti-inflammatory drug (NSAID), aspirin can inhibit COX-1 in platelets to reduce $\mathrm{PGE}_{2}$ and $\mathrm{TXA}_{2}$, subsequently attenuating the tumor metastasis (237). Long-term clinical trials showed that taking aspirin daily $(>75 \mathrm{mg}$ ) for years brought down incidence and mortality of colorectal cancer, especially the proximal colon cancer (238). Aside from colorectal cancer, aspirin use is capable of decreasing the risk of gastric cancer (239), pancreatic cancer (240) and cholangiocarcinoma (241) and increasing the survival of advanced-stage prostate cancer (242), breast cancer (243) and endometrial cancer (244). However, some other clinical studies showed that aspirin had no effects on cancer risk (245) or cancerspecific death $(246,247)$. Therefore, more randomized clinical trials are needed to validate the preventive and therapeutic effects of aspirin on cancer treatment.

Other antiplatelet drugs including antagonists of ADP receptor $\mathrm{P}_{2} \mathrm{Y}_{12}$, integrins ( $\alpha \operatorname{IIb} \beta 3, \alpha 2 \beta 1$ ), P-selectin, CLEC-2 (7) are all being investigated. Of note, there are some natural materials acting as antiplatelet agents. Irfan et al. recently identified Eisenia bicyclis as a potential anti-thrombotic agent for cardiovascular disease (CVD) and possibly cancer with fewer side effects. Eisenia bicyclis inhibited ADP-induced platelet aggregation by suppressing PI3K/Akt signaling and MAPK activation in a dose-dependent manner (248). Norcantharidin (NCTD), a demethylated analogue of cantharidin, is clinically utilized for cancer chemotherapy in China for years (249). It was found to have powerful antiplatelet effects through suppression of integrin aIIb $\beta 3$ mediated outside-in signaling in human platelets (250).

However, most of these antiplatelet agents are still in the early stages and lack statistical power for wide clinical application. Moreover, use of antiplatelet agents likely leads to thrombocytopenia and bleeding complication $(8,251)$. Some studies even suggested that long-term inhibition of platelet function could pose a hazard in return $(252,253)$. In fact, it was found that $4 \mathrm{~T} 1$ metastatic breast cancer-bearing mice had reduced survival when treated with dual platelet inhibitors clopidogrel and aspirin (254).

Fortunately, some novel platelet inhibitors have appeared with a more favorable safety profile. Investigators have found that ruthenium complexes with antiplatelet properties (255) exerted higher efficacy and lower side effects in cancer therapy $(256,257)$, in comparison with standard cisplatin and carboplatin therapies $(258,259)$. Thanasekaran et al. have reviewed the molecular mechanisms of ruthenium compounds in repressing platelet activation (255). Ruthenium complexes TQ3 (260), TQ5 (261) and TQ6 (262) could reduce granule secretion and hinder platelet activation and aggregation. More importantly, ruthenium compounds exhibited higher cytotoxicity in cancer cells than normal cells (263) and showed improved safety without increased $\mathrm{LDH}$ activity in platelets (260-262). As is known, human platelet-expressed NADPH oxidases (NOX) accelerate reactive oxygen species (ROS) generation and activate platelets (264). Recently, NOX2 inhibitor Phox-I was observed to disrupt platelet activation without altering the hemostatic response to injury. It was capable of reducing platelet ATP secretion, calcium level and restricting $\mathrm{PI} 3 \mathrm{~K}$ signaling and $\mathrm{p} 38$-MAPK in thrombinstimulated platelets (265).

The above data demonstrate that antiplatelet drugs have great potentialities for clinical application. In consideration of physiological functions of platelets, how to reduce the side effects of antiplatelet agents will be a pivotal issue in the future.

\subsection{Platelet-Based Drug Delivery System}

Recently, Lu et al. provided a comprehensive description of platelet-mediated drug delivery systems that include platelet hitchhiking, membrane coating, platelet engineering, synthetic platelet fabrication and platelet-triggered drug release (266). By binding to platelets through targeting platelet adhesion molecules (e.g. GPIIb/IIIa, P-selectin, phosphatidylserine), nanoparticles with anti-thrombosis drugs (267) or anticancer drugs (268) could become powerful targeted drugs (266). However, Chen et al. revealed that the platelet targeting effects of magnetic nanoparticles (MNPs) varied due to distinct tumoral microenvironment. MNPs were effective in breast cancer with adequate blood supply and low extracellular matrix (ECM) expression, but not in ischemic pancreatic cancer (268).

Synthetic silica particles with platelet membrane (PM) can also be used to deliver anti-cancer drugs to CTCs. Tumor necrosis factor-related apoptosis inducing ligand (TRAIL) on the particle surface was shown to specifically induce apoptosis of cancer cells (269). Hu et al. designed a PM-coated core-shell nano-vehicle with TRAIL and Dox (TRAIL-Dox-PM-NV). Through the interaction between P-selectin on PM and CD44 receptors on the cancer cells, TRAIL-Dox-PM-NV aggregated at the surface of CTCs and suppressed their survival and spreading (270). Similarly, a newly PM-decorated nanoparticle that incorporated both DOX and a photothermal agent, indocyanine green (ICG), had the capability to track CTCs in lymph nodes and blood through P-selectin-CD44 interplay and eliminate CTCs by releasing DOX and ICG. It exhibited strong inhibitory effects on orthotopic tumor growth and metastasis in breast cancer (271).

In platelet engineering, platelets could load drugs via platelet surface modification, platelet phagocytosis, or genetic manipulation of megakaryocytes (266). DOX loaded-platelets could augment therapeutic effects of lymphoma with less cardiotoxicity (272), while interferon- $\gamma$ induced protein 10 (IP10)-loaded platelets could inhibit tumor growth and increase anti-tumor immunity by reducing regulatory $\mathrm{T}$ cells in melanoma model (273). Zhang et al. constructed engineered platelets expressing the programmed cell death protein 1 (PD-1) to prevent tumor relapse after surgical resection. These recombinant platelets could aggregate at the surgical wound sites and eradicate residual tumor cells by reverting CD8+ $\mathrm{T}$ 
cells. Moreover, cyclophosphamide carried by such platelets could exhaust regulatory $\mathrm{T}$ cells and promote the anticancer effects of CD8+ T cells (274). Intriguingly, investigators found that the conjugate of hematopoietic stem cells (HSCs) and platelets decorated with anti-PD-1 antibodies (aPD-1) could enter the bone marrow due to the homing capability of HSCs. Then platelets were activated in leukemia microenvironment and released aPD-1 to enhance immune response in mice with acute myeloid leukaemia (275). They further genetically modified mouse MK progenitor cells that produced PD-1-presenting platelets under stimulation. These platelets could effectively gather at tumor resection site via thrombosis and PD-1/PD-L1 interaction and thus inhibit the tumor recurrence. The therapeutic potency was enhanced when PD-1-presenting platelets were loaded with cyclophosphamide (276). In addition, Li et al. developed a strategy that combined Vadimezan and aPDL1-loaded platelets to inhibit tumor metastases. Vadimezan disrupted tumor blood vessels and then recruited aPDL1-conjugated platelets at the tumor site, leading to immune activation and enhanced antitumor effects (277).
Recently, Papa et al. developed detergent-extracted human modified platelets (platelet decoys) that retained binding capacity but couldn't aggregate in response to platelet agonists. Importantly, decoys inhibited aggregation and adhesion of natural platelets and then halted blood clot formation and cancer spread, which could be reversed immediately by transfusing functional platelets. Papa's team believed that decoys had the potential to be loaded with drugs and specifically target thrombosis, tumors or CTCs (278).

These studies support the notion that modified platelets or particles that mimic platelets are able to deliver antineoplastic drugs or antitumor proteins to CTCs with prolonged circulation time, achieving potent antitumor effects. Since platelets also play an important part in thrombosis formation, this method may also be useful for cardiovascular disease. Nonetheless, since platelets can be attracted to damaged vasculature and carry out their physiological functions, platelet-based drug delivery system may cause off-target effects. In this regards, it should be noted that there are reports demonstrating that platelets were innate immune cells and exhibited some anti-cancer properties (279),

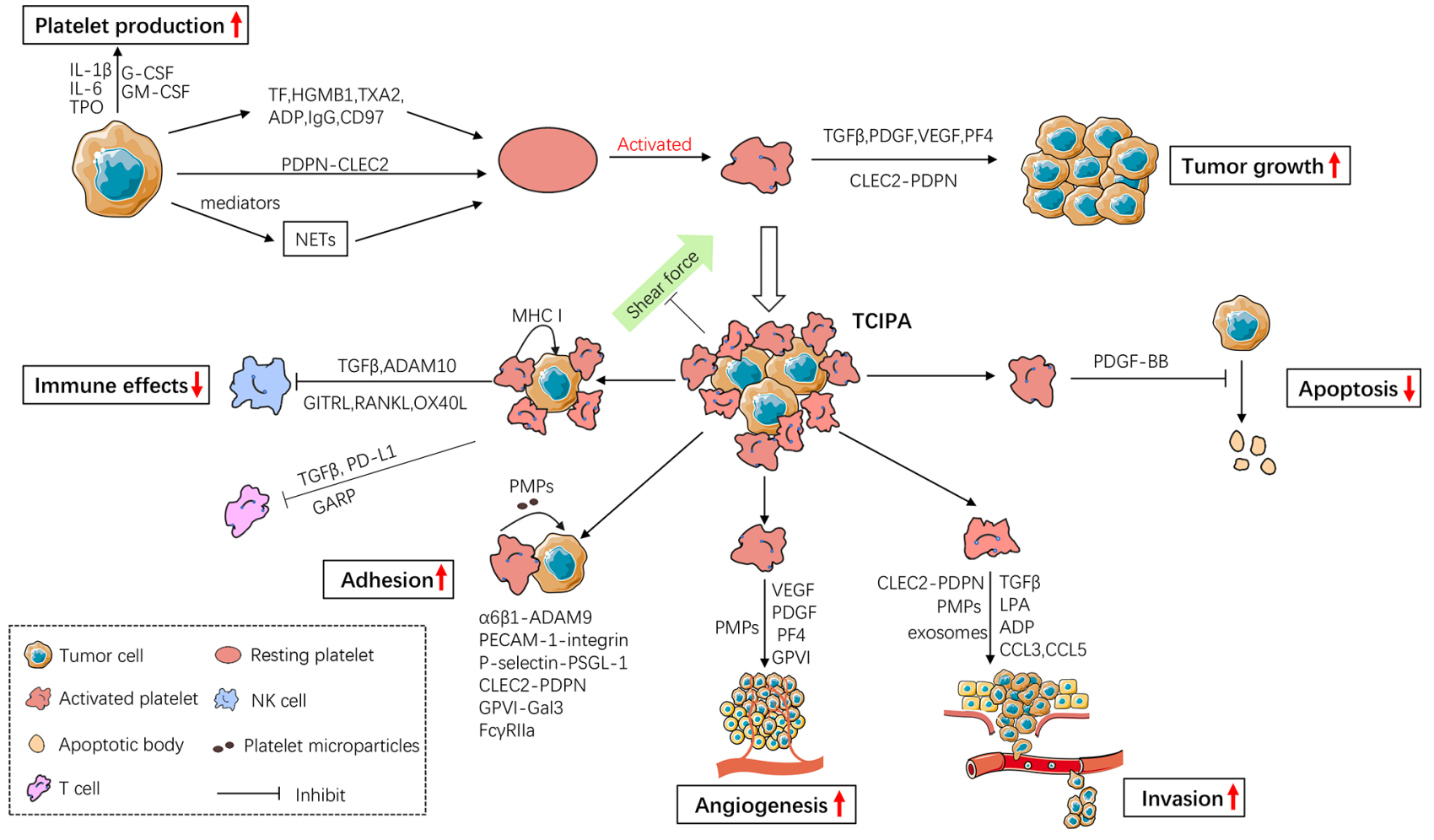

FIGURE 1 | The bidirectional interaction between cancer cells and platelets. Cancer cells promote platelet production and activation, while activated platelets release a number of mediators to facilitate tumor growth and cancer cell metastasis. Activated platelets prevent circulating cancer cells (CTCs) from shear flow, immune surveillance and apoptosis, thus enhancing CTC survival in circulation. They also facilitate CTC adhesion, angiogenesis and invasion thereby enhancing metastasis.

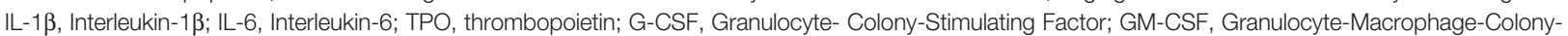
Stimulating Factor; TF, Tissue Factor; HGMB1, High-Mobility Group Box1; TXA2, Thromboxane A2; IgG, immunoglobulin G; PDPN, Podoplanin; CLEC2, C-type lectin receptor type 2; NETs, Neutrophil Extracellular Traps; TGF $\beta$, Transforming Growth Factor $\beta$; PDGF, Platelet-Derived Growth Factor; VEGF, Vascular Endothelial Growth Factor; PF4, Platelet Factor 4; TCIPA, Tumor Cell-Induced Platelet Aggregation; MHC I, MHC class I; ADAM10, Disintegrin And Metalloproteinase DomainContaining Protein 10; GITRL, Glucocorticoid-Induced TNF Receptor-Related Ligand; RANKL, Receptor Activator of NF-кB Ligand; OX40L, Oxford 40 Ligand; GARP, Glycoprotein A Repetitions Predominant; PD-L1, Programmed Cell Death-Ligand 1; PMPs, Platelet Microparticles; PECAM-1, Platelet-Endothelial Cell Adhesion Molecule-1; PSGL-1, P-selectin Glycoprotein Ligand-1. 
protected endothelial barrier and decreased cancer cell intravasation and extravasation (280). Above all, considering the close interaction between platelets and cancer, platelets can be converted to anti-cancer drug delivery vehicles. Compared with other tumor-targeting nanoparticles, platelet-derived vehicles have some remarkable advantages including prolonged circulation time and large cargo capacity (281). Large clinical trials are warranted to confirm the therapeutic values of platelets and platelet-derived particles.

\section{CONCLUDING REMARKS}

Overwhelming evidence supports an auxiliary positive role of platelets in promoting both primary cancer and metastatic cancer. As illustrated in Figure 1, the interaction between tumor cells and platelets is bidirectional. On one hand, as a component of the tumor microenvironment, platelets are educated by cancer cells to facilitate survival and dissemination of cancer cells. On the other hand, cancer cells induce platelet production, activation and aggregation to increase the risk of thrombosis in cancer patients. Studying the interplay of platelets with cancer cells has major implications for diagnosis and treatment of cancers. Platelet counts, RNA profile, proteome and platelet-derived factors/microparticles in cancer patients can be used for early cancer detection, prognosis monitoring and assessment of chemotherapy curative effects. Antiplatelet and

\section{REFERENCES}

1. Franco AT, Corken A, Ware J. Platelets at the Interface of Thrombosis, Inflammation, and Cancer. Blood (2015) 126(5):582-8. doi: 10.1182/blood2014-08-531582

2. Dovizio M, Sacco A, Patrignani P. Curbing Tumorigenesis and Malignant Progression Through the Pharmacological Control of the Wound Healing Process. Vascul Pharmacol (2017) 89:1-11. doi: 10.1016/j.vph.2017.01.003

3. Arwert EN, Hoste E, Watt FM. Epithelial Stem Cells, Wound Healing and Cancer. Nat Rev Cancer (2012) 12(3):170-80. doi: 10.1038/nrc3217

4. Menter DG, Kopetz S, Hawk E, Sood AK, Loree JM, Gresele P, et al. Platelet "First Responders" in Wound Response, Cancer, and Metastasis. Cancer Metastasis Rev (2017) 36(2):199-213. doi: 10.1007/s10555-017-9682-0

5. Plantureux L, Mege D, Crescence L, Dignat-George F, Dubois C, PanicotDubois L. Impacts of Cancer on Platelet Production, Activation and Education and Mechanisms of Cancer-Associated Thrombosis. Cancers (Basel) (2018) 10(11):441. doi: 10.3390/cancers10110441

6. Haemmerle M, Stone RL, Menter DG, Afshar-Kharghan V, Sood AK. The Platelet Lifeline to Cancer: Challenges and Opportunities. Cancer Cell (2018) 33(6):965-83. doi: 10.1016/j.ccell.2018.03.002

7. Bruno A, Dovizio M, Tacconelli S, Contursi A, Ballerini P, Patrignani P. Antithrombotic Agents and Cancer. Cancers (Basel) (2018) 10(8):253. doi: $10.3390 /$ cancers 10080253

8. Gresele P, Momi S, Malvestiti M, Sebastiano M. Platelet-Targeted Pharmacologic Treatments as Anti-Cancer Therapy. Cancer Metastasis Rev (2017) 36(2):331-55. doi: 10.1007/s10555-017-9679-8

9. Hu C, Chen R, Chen W, Pang W, Xue X, Zhu G, et al. Thrombocytosis is a Significant Indictor of Hypercoagulability, Prognosis and Recurrence in Gastric Cancer. Exp Ther Med (2014) 8(1):125-32. doi: 10.3892/ etm.2014.1699

10. Wang L, Huang X, Chen Y, Jin X, Li Q, Yi TN. Prognostic Value of TP/PDECGF and Thrombocytosis in Gastric Carcinoma. Eur J Surg Oncol (2012) 38(7):568-73. doi: 10.1016/j.ejso.2012.04.008 anti-thrombosis drugs have promising prospects for cancer treatment. Moreover, combination of platelet inhibition and other therapy strategies (such as photothermal therapy) may achieve synergistic and potent anticancer effects (282). However, many questions still remain to be answered, such as how to control the degree of platelet inhibition without disrupting their physiological functions and what kinds of patients are suitable for using antiplatelet agents. Platelet-based drug delivery system is an innovative method for cancer therapy, but how to avoid offtarget effects is the greatest challenge.

\section{AUTHOR CONTRIBUTIONS}

All authors listed were contributed to the manuscript writing and revising. They all approved the submitted version.

\section{FUNDING}

The work was supported by Guangdong Provincial Key Laboratory of Digestive Cancer Research (No. 2021B1212040006), National Natural Science Foundation of China (NSFC, No. 82000150), Shenzhen Science and Technology Innovation Commission (JCYJ20190809172403604, JCYJ20190809164617205) and Sanming Project of Medicine in Shenzhen (No. SZSM202011011).

11. Zhao JM, Wang YH, Yao N, Wei KK, Jiang L, Hanif S, et al. Poor Prognosis Significance of Pretreatment Thrombocytosis in Patients With Colorectal Cancer: A Meta-Analysis. Asian Pac J Cancer Prev (2016) 17(9):4295-300. doi: 10.14456/apjcp.2016.254

12. Kozak MM, von Eyben R, Pai JS, Anderson EM, Welton ML, Shelton AA, et al. The Prognostic Significance of Pretreatment Hematologic Parameters in Patients Undergoing Resection for Colorectal Cancer. Am J Clin Oncol (2017) 40(4):405-12. doi: 10.1097/COC.0000000000000183

13. Stravodimou A, Voutsadakis IA. Pretreatment Thrombocytosis as a Prognostic Factor in Metastatic Breast Cancer. Int J Breast Cancer (2013) 2013:289563. doi: 10.1155/2013/289563

14. Taucher S, Salat A, Gnant M, Kwasny W, Mlineritsch B, Menzel RC, et al. Impact of Pretreatment Thrombocytosis on Survival in Primary Breast Cancer. Thromb Haemost (2003) 89(6):1098-106. doi: 10.1055/s-0037-1613413

15. Wang YH, Kang JK, Zhi YF, Zhang Y, Wang ZQ, Zhou Q, et al. The Pretreatment Thrombocytosis as One of Prognostic Factors for Gastric Cancer:A Systematic Review and Meta-Analysis. Int J Surg (2018) 53:30411. doi: 10.1016/j.ijsu.2018.03.084

16. Zhou Q, Huang F, He Z, Zuo MZ. Clinicopathological and Prognostic Significance of Platelet Count in Patients With Ovarian Cancer. Climacteric (2018) 21(1):60-8. doi: 10.1080/13697137.2017.1406911

17. Sasaki K, Kawai K, Tsuno NH, Sunami E, Kitayama J. Impact of Preoperative Thrombocytosis on the Survival of Patients With Primary Colorectal Cancer. World J Surg (2012) 36(1):192-200. doi: 10.1007/s00268-0111329-7

18. Pang Q, Qu K, Zhang JY, Song SD, Liu SS, Tai MH, et al. The Prognostic Value of Platelet Count in Patients With Hepatocellular Carcinoma: A Systematic Review and Meta-Analysis. Med (Baltimore) (2015) 94(37): e1431. doi: 10.1097/MD.0000000000001431

19. Yang C, Jiang H, Huang S, Hong H, Huang X, Wang X, et al. The Prognostic Role of Pretreatment Thrombocytosis in Gastric Cancer: A Systematic Review and Meta-Analysis. Med (Baltimore) (2018) 97(31):e11763. doi: 10.1097/MD.0000000000011763 
20. Agoston AT, Srivastava A, Zheng Y, Bueno R, Odze RD, Szallasi Z. Paraneoplastic Thrombocytosis Is Associated With Increased Mortality and Increased Rate of Lymph Node Metastasis in Oesophageal Adenocarcinoma. Pathology (2017) 49(5):471-5. doi: 10.1016/j.pathol. 2017.04.001

21. Miyama Y, Morikawa T, Miyakawa J, Koyama Y, Kawai T, Kume H, et al. The Prognostic Value of PD-L1 Expression in Upper Tract Urothelial Carcinoma Varies According to Platelet Count. Cancer Med (2018) 7 (9):4330-8. doi: 10.1002/cam4.1686

22. Zhang W, Liu X, Cheng H, Yang Z, Zhang G. Risk Factors and Treatment of Venous Thromboembolism in Perioperative Patients With Ovarian Cancer in China. Med (Baltimore) (2018) 97(31):e11754. doi: 10.1097/MD. 0000000000011754

23. Xu F, Li Y, Fan L, Ma J, Yu L, Yi H, et al. Preoperative SCC-Ag and Thrombocytosis as Predictive Markers for Pelvic Lymphatic Metastasis of Squamous Cervical Cancer in Early FIGO Stage. J Cancer (2018) 9(9):16606. doi: $10.7150 /$ jca. 24049

24. Li FX, Wei LJ, Zhang H, Li SX, Liu JT. Significance of Thrombocytosis in Clinicopathologic Characteristics and Prognosis of Gastric Cancer. Asian Pac J Cancer Prev (2014) 15(16):6511-7. doi: 10.7314/APJCP.2014.15.16.6511

25. Wan S, Lai Y, Myers RE, Li B, Hyslop T, London J, et al. Preoperative Platelet Count Associates With Survival and Distant Metastasis in Surgically Resected Colorectal Cancer Patients. J Gastrointest Cancer (2013) 44 (3):293-304. doi: 10.1007/s12029-013-9491-9

26. Yang L, Dong H, Li Z, Pan Y, Qu and Z. Tan: Correlation Between Circulating Tumor Cells and D-D and Platelet in Patients With Pulmonary Malignancies. Oncol Lett (2018) 15(2):2169-72. doi: 10.3892/ ol.2017.7595

27. Shimada H, Oohira G, Okazumi S, Matsubara H, Nabeya Y, Hayashi H, et al. Thrombocytosis Associated With Poor Prognosis in Patients With Esophageal Carcinoma. J Am Coll Surg (2004) 198(5):737-41. doi: 10.1016/j.jamcollsurg.2004.01.022

28. Ling FC, Vallbohmer D, Hoelscher AH, Schmidt D, Bollschweiler E, Schneider PM. Increased Platelet Counts After Transthoracic En Bloc Resection for Esophageal Cancer Is Associated With Significantly Improved Survival. World J Surg (2010) 34(11):2628-34. doi: 10.1007/ s00268-010-0707-x

29. Aminian A, Karimian F, Mirsharifi R, Alibakhshi A, Dashti H, Jahangiri Y, et al. Significance of Platelet Count in Esophageal Carcinomas. Saudi J Gastroenterol (2011) 17(2):134-7. doi: 10.4103/1319-3767.77245

30. Dutta S, Crumley AB, Fullarton GM, Horgan PG, McMillan DC. Comparison of the Prognostic Value of Tumour- and Patient-Related Factors in Patients Undergoing Potentially Curative Resection of Oesophageal Cancer. World J Surg (2011) 35(8):1861-6. doi: 10.1007/ s00268-011-1130-7

31. Harano K, Kogawa T, Wu J, Yuan Y, Cohen EN, Lim B, et al. Thrombocytosis as a Prognostic Factor in Inflammatory Breast Cancer. Breast Cancer Res Treat (2017) 166(3):819-32. doi: 10.1007/s10549-0174463-6

32. Ankus E, Price SJ, Ukoumunne OC, Hamilton W, Bailey S. Cancer Incidence in Patients With a High Normal Platelet Count: A Cohort Study Using Primary Care Data. Fam Pract (2018) 35(6):671-5. doi: 10.1093/fampra/ cmy018

33. Biino G, Santimone I, Minelli C, Sorice R, Frongia B, Traglia M, et al. Ageand Sex-Related Variations in Platelet Count in Italy: A Proposal of Reference Ranges Based on 40987 Subjects' Data. PloS One (2013) 8(1): e54289. doi: 10.1371/journal.pone.0054289

34. Santimone I, Di Castelnuovo A, De Curtis A, Spinelli M, Cugino D, Gianfagna F, et al. White Blood Cell Count, Sex and Age Are Major Determinants of Heterogeneity of Platelet Indices in an Adult General Population: Results From the MOLI-SANI Project. Haematologica (2011) 96(8):1180-8. doi: 10.3324/haematol.2011.043042

35. Bonaccio M, Di Castelnuovo A, Costanzo S, De Curtis A, Donati MB, Cerletti C, et al. Age-Sex-Specific Ranges of Platelet Count and All-Cause Mortality: Prospective Findings From the MOLI-SANI Study. Blood (2016) 127(12):1614-6. doi: 10.1182/blood-2016-01-692814

36. Li L, Wang J, Meng S, Li Z, Huang Z, Sun J, et al. Peripheral Blood Leukocytes and Platelets Serve as Prognostic Factors in Breast Cancer.
Cancer Biother Radiopharm (2021) 36(2):167-73. doi: 10.1089/ cbr.2019.3032

37. Vayrynen JP, Vayrynen SA, Sirnio P, Minkkinen I, Klintrup K, Karhu T, et al. Platelet Count, Aspirin Use, and Characteristics of Host Inflammatory Responses in Colorectal Cancer. J Transl Med (2019) 17(1):199. doi: 10.1186/ s12967-019-1950-z

38. Ishibashi Y, Tsujimoto H, Sugasawa H, Kouzu K, Itazaki Y, Sugihara T, et al. Prognostic Value of Platelet-Related Measures for Overall Survival in Esophagealsquamous Cell Carcinoma: A Systematic Review and MetaAnalysis. Crit Rev Oncol Hematol (2021) 164:103427. doi: 10.1016/ j.critrevonc.2021.103427

39. Nost TH, Alcala K, Urbarova I, Byrne KS, Guida F, Sandanger TM, et al. Systemic Inflammation Markers and Cancer Incidence in the UK Biobank. Eur J Epidemiol (2021) 36(8):841-8. doi: 10.1007/s10654-021-00752-6

40. Zhang J, Feng W, Ye Z, Wei Y, Li L, Yang Y. Prognostic Significance of Platelet-to-Lymphocyte Ratio in Patients With Nasopharyngeal Carcinoma: A Meta-Analysis. Future Oncol (2020) 16(5):117-27. doi: 10.2217/fon-20190520

41. Zhang Y, Zheng L, Quan L. And Du L: Prognostic Role of Platelet-toLymphocyte Ratio in Oral Cancer: A Meta-Analysis. J Oral Pathol Med (2021) 50(3):274-9. doi: 10.1111/jop.12832

42. Xu SS, Li S, Xu HX, Li H, Wu CT, Wang WQ, et al. Haemoglobin, Albumin, Lymphocyte and Platelet Predicts Postoperative Survival Inpancreatic Cancer. World J Gastroenterol (2020) 26(8):828-38. doi: 10.3748/ wjg.v26.i8.828

43. Gunduz S, Mutlu H, Tural D, Yildiz O, Uysal M, Coskun HS, et al. Platelet to Lymphocyte Ratio as a New Prognostic for Patients With Metastatic Renal Cell Cancer. Asia Pac J Clin Oncol (2015) 11(4):288-92. doi: 10.1111/ ajco. 12358

44. Ma JY, Ke LC, Liu Q. The Pretreatment Platelet-to-Lymphocyte Ratio Predicts Clinical Outcomes in Patients With Cervical Cancer: A MetaAnalysis. Med (Baltimore) (2018) 97(43):e12897. doi: 10.1097/MD. 0000000000012897

45. Zhang GM, Zhu Y, Luo L, Wan FN, Zhu YP, Sun LJ, et al. Preoperative Lymphocyte-Monocyte and Platelet-Lymphocyte Ratios as Predictors Ofoverall Survival in Patients With Bladder Cancer Undergoing Radical Cystectomy. Tumour Biol (2015) 36(11):8537-43. doi: 10.1007/s13277-0153613-x

46. Kilincalp S, Coban S, Akinci H, Hamamci M, Karaahmet F, Coskun Y, et al. Neutrophil/lymphocyte Ratio, Platelet/Lymphocyte Ratio, and Mean Platelet Volumeas Potential Biomarkers for Early Detection and Monitoring of Colorectal Adenocarcinoma. Eur J Cancer Prev (2015) 24(4):328-33. doi: 10.1097/CEJ.0000000000000092

47. Takenaka Y, Oya R, Kitamiura T, Ashida N, Shimizu K, Takemura K, et al. Platelet Count and Platelet-Lymphocyte Ratio as Prognostic Markers for Head and Neck Squamous Cell Carcinoma: A Meta-Analysis. Head Neck (2018) 40(12):2714-23. doi: 10.1002/hed.25366

48. Aldemir MN, Turkeli M, Simsek M, Yildirim N, Bilen Y, Yetimoglu H, et al. Prognostic Value of Baseline Neutrophil-Lymphocyte and PlateletLymphocyte Ratios in Local and Advanced Gastric Cancer Patients. Asian Pac J Cancer Prev (2015) 16(14):5933-7. doi: 10.7314/APJCP.2015.16.14.5933

49. Huang Z, Liu Y, Yang C, Li X, Pan C, Rao J, et al. Combined Neutrophil/ Platelet/Lymphocyte/Differentiation Score Predicts Chemosensitivity in Advanced Gastric Cancer. BMC Cancer (2018) 18(1):515. doi: 10.1186/ s12885-018-4414-6

50. Timp JF, Braekkan SK, Versteeg HH, Cannegieter SC. Epidemiology of Cancer-Associated Venous Thrombosis. Blood (2013) 122(10):1712-23. doi: 10.1182/blood-2013-04-460121

51. Khorana AA, Francis CW, Culakova E, Kuderer NM, Lyman GH Thromboembolism Is a Leading Cause of Death in Cancer Patients Receiving Outpatient Chemotherapy. J Thromb Haemost (2007) 5(3):6324. doi: 10.1111/j.1538-7836.2007.02374.x

52. Zhang Y, Wang C, Yu M, Zhao X, Du J Y, Jing H, et al. Neutrophil Extracellular Traps Induced by Activated Platelets Contribute to Procoagulant Activity in Patients With Colorectal Cancer. Thromb Res (2019) 180:87-97. doi: 10.1016/j.thromres.2019.06.005

53. Mitrugno A, Tassi YS, Sylman JL, Zilberman-Rudenko J, Shirai T, Hebert JF, et al. The Role of Coagulation and Platelets in Colon Cancer-Associated 
Thrombosis. Am J Physiol Cell Physiol (2019) 316(2):C264-73. doi: 10.1152/ ajpcell.00367.2018

54. von Schweinitz D, Hadam MR, Welte K, Mildenberger H, Pietsch T. Production of Interleukin-1 Beta and Interleukin-6 in Hepatoblastoma. Int J Cancer (1993) 53(5):728-34. doi: 10.1002/ijc.2910530504

55. Higashihara M, Sunaga S, Tange T, Oohashi H, Kurokawa K. Increased Secretion of Interleukin-6 in Malignant Mesothelioma Cells From a Patient With Marked Thrombocytosis. Cancer-Am Cancer Soc (1992) 70(8):2105-8. doi: $10.1002 / 1097-0142(19921015) 70: 8<2105:: a i d-c n c r 2820700816>$ 3.0.co;2-r

56. Gastl G, Plante M, Finstad CL, Wong GY, Federici MG, Bander NH, et al. High IL-6 Levels in Ascitic Fluid Correlate With Reactive Thrombocytosis in Patients With Epithelial Ovarian Cancer. Br J Haematol (1993) 83(3):43341. doi: $10.1111 /$ j.1365-2141.1993.tb04668.x

57. Suzuki A, Takahashi T, Nakamura K, Tsuyuoka R, Okuno Y, Enomoto T, et al. Thrombocytosis in Patients With Tumors Producing ColonyStimulating Factor. Blood (1992) 80(8):2052-9. doi: 10.1182/ blood.V80.8.2052.2052

58. Ryu T, Nishimura S, Miura H, Yamada H, Morita H, Miyazaki H, et al. Thrombopoietin-Producing Hepatocellular Carcinoma. Intern Med (2003) 42(8):730-4. doi: 10.2169/internalmedicine.42.730

59. Stone RL, Nick AM, McNeish IA, Balkwill F, Han HD, Bottsford-Miller J, et al. Paraneoplastic Thrombocytosis in Ovarian Cancer. $N$ Engl J Med (2012) 366(7):610-8. doi: 10.1056/NEJMoa1110352

60. Kaushansky K, Lok S, Holly RD, Broudy VC, Lin N, Bailey MC, et al. Promotion of Megakaryocyte Progenitor Expansion and Differentiation by the C-Mplligand Thrombopoietin. Nature (1994) 369(6481):568-71. doi: $10.1038 / 369568 \mathrm{a} 0$

61. Kaser A, Brandacher G, Steurer W, Kaser S, Offner FA, Zoller H, et al. Interleukin-6 Stimulates Thrombopoiesis Through Thrombopoietin: Role in Inflammatory Thrombocytosis. Blood (2001) 98(9):2720-5. doi: 10.1182/ blood.V98.9.2720

62. Josa V, Ferenczi S, Szalai R, Fuder E, Kuti D, Horvath K, et al. Thrombocytosis and Effects of IL-6 Knock-Out in a Colitis-Associated Cancer Model. Int J Mol Sci (2020) 21(17):6218. doi: 10.3390/ijms21176218

63. McCarty JM, Sprugel KH, Fox NE, Sabath DE, Kaushansky K. Murine Thrombopoietin mRNA Levels Are Modulated by Platelet Count. Blood (1995) 86(10):3668-75. doi: 10.1182/blood.V86.10.3668.bloodjournal 86103668

64. Hill CN, Hernandez-Caceres MP, Asencio C, Torres B, Solis B, Owen GI. Deciphering the Role of the Coagulation Cascade and Autophagy in CancerRelated Thrombosis and Metastasis. Front Oncol (2020) 10:605314. doi: $10.3389 /$ fonc. 2020.605314

65. Klement GL, Yip TT, Cassiola F, Kikuchi L, Cervi D, Podust V, et al. Platelets Actively Sequester Angiogenesis Regulators. Blood (2009) 113(12):2835-42. doi: 10.1182/blood-2008-06-159541

66. Cervi D, Yip TT, Bhattacharya N, Podust VN, Peterson J, Abou-Slaybi A, et al. Platelet-Associated PF-4 as a Biomarker of Early Tumor Growth. Blood (2008) 111(3):1201-7. doi: 10.1182/blood-2007-04-084798

67. Peterson JE, Zurakowski D, Italiano JJ, Michel LV, Connors S, Oenick M, et al. VEGF, PF4 and PDGF Are Elevated in Platelets of Colorectal Cancer Patients. Angiogenesis (2012) 15(2):265-73. doi: 10.1007/s10456012-9259-Z

68. Best MG, Sol N, Kooi I, Tannous J, Westerman BA, Rustenburg F, et al. RNA-Seq of Tumor-Educated Platelets Enables Blood-Based Pan-Cancer, Multiclass, and Molecular Pathway Cancer Diagnostics. Cancer Cell (2015) 28(5):666-76. doi: 10.1016/j.ccell.2015.09.018

69. Xue L, Xie L, Song X, Song X. Identification of Potential Tumor-Educated Platelets RNA Biomarkers in Non-Small-Cell Lung Cancer by Integrated Bioinformatical Analysis. J Clin Lab Anal (2018) 32(7):e22450. doi: 10.1002/ jcla. 22450

70. Calverley DC, Phang TL, Choudhury QG, Gao B, Oton AB, Weyant MJ, et al. Significant Downregulation of Platelet Gene Expression in Metastatic Lung Cancer. Clin Transl Sci (2010) 3(5):227-32. doi: 10.1111/j.17528062.2010.00226.x

71. Zu R, Yu S, Yang G, Ge Y, Wang D, Zhang L, et al. Integration of Platelet Features in Blood and Platelet Rich Plasma for Detectionof Lung Cancer. Clin Chim Acta (2020) 509:43-51. doi: 10.1016/j.cca.2020.05.043
72. Sabrkhany S, Kuijpers M, van Kuijk S, Sanders L, Pineda S, Olde DS, et al. A Combination of Platelet Features Allows Detection of Early-Stage Cancer. Eur J Cancer (2017) 80:5-13. doi: 10.1016/j.ejca.2017.04.010

73. Zhang Q, Hu H, Liu H, Jin J, Zhu P, Wang S, et al. RNA Sequencing Enables Systematic Identification of Platelet Transcriptomic Alterations in NSCLC Patients. Biomed Pharmacother (2018) 105:204-14. doi: 10.1016/ j.biopha.2018.05.074

74. Liu L, Song X, Li X, Xue L, Ding S, Niu L, et al. A Three-Platelet mRNA Set: MAX, MTURN and HLA-B as Biomarker for Lung Cancer. J Cancer Res Clin Oncol (2019) 145(11):2713-23. doi: 10.1007/s00432-019-03032-9

75. Joosse SA, Pantel K. Tumor-Educated Platelets as Liquid Biopsy in Cancer Patients. Cancer Cell (2015) 28(5):552-4. doi: 10.1016/j.ccell.2015.10.007

76. Feller SM, Lewitzky M. Hunting for the Ultimate Liquid Cancer Biopsy - Let the TEP Dance Begin. Cell Commun Signal (2016) 14(1):24. doi: 10.1186/ s12964-016-0147-9

77. Yang L, Jiang Q, Li DZ, Zhou X, Yu DS, Zhong J. TIMP1 mRNA in TumorEducated Platelets Is Diagnostic Biomarker for Colorectal Cancer. Aging (Albany NY) (2019) 11(20):8998-9012. doi: 10.18632/aging.102366

78. Best MG, In TVS, Sol N, Wurdinger T. RNA Sequencing and Swarm Intelligence-Enhanced Classification Algorithm Development for BloodBased Disease Diagnostics Using Spliced Blood Platelet RNA. Nat Protoc (2019) 14(4):1206-34. doi: 10.1038/s41596-019-0139-5

79. Skog J, Wurdinger T, van Rijn S, Meijer DH, Gainche L, Sena-Esteves M, et al. Glioblastoma Microvesicles Transport RNA and Proteins That Promote Tumour Growthand Provide Diagnostic Biomarkers. Nat Cell Biol (2008) 10(12):1470-6. doi: 10.1038/ncb1800

80. Liu C, Yu S, Zinn K, Wang J, Zhang L, Jia Y, et al. Murine Mammary Carcinoma Exosomes Promote Tumor Growth by Suppression of NK Cellfunction. J Immunol (2006) 176(3):1375-85. doi: 10.4049/ jimmunol.176.3.1375

81. Abusamra AJ, Zhong Z, Zheng X, Li M, Ichim TE, Chin JL, et al. Tumor Exosomes Expressing Fas Ligand Mediate CD8+ T-Cell Apoptosis. Blood Cells Mol Dis (2005) 35(2):169-73. doi: 10.1016/j.bcmd.2005.07.001

82. Nilsson RJ, Balaj L, Hulleman E, van Rijn S, Pegtel DM, Walraven M, et al. Blood Platelets Contain Tumor-Derived RNA Biomarkers. Blood (2011) 118 (13):3680-3. doi: 10.1182/blood-2011-03-344408

83. Zaslavsky A, Baek KH, Lynch RC, Short S, Grillo J, Folkman J, et al. PlateletDerived Thrombospondin-1 Is a Critical Negative Regulator and Potentialbiomarker of Angiogenesis. Blood (2010) 115(22):4605-13. doi: 10.1182/blood-2009-09-242065

84. Sabrkhany S, Griffioen AW, Oude EM. The Role of Blood Platelets in Tumor Angiogenesis. Biochim Biophys Acta (2011) 1815(2):189-96. doi: 10.1016/ j.bbcan.2010.12.001

85. Yao L, Dong H, Luo Y, Du J, Hu W. Net Platelet Angiogenic Activity (NPAA) Correlates With Progression and Prognosis of Non-Small Cell Lung Cancer. PloS One (2014) 9(4):e96206. doi: 10.1371/journal.pone.0096206

86. Alkozai EM, Porte RJ, Adelmeijer J, Zanetto A, Simioni P, Senzolo M, et al. Levels of Angiogenic Proteins in Plasma and Platelets Are Not Different Between Patients With Hepatitis B/C-Related Cirrhosis and Patients With Cirrhosis and Hepatocellular Carcinoma. Platelets (2015) 26(6):577-82. doi: 10.3109/09537104.2014.961415

87. Sabrkhany S, Kuijpers M, Knol JC, Olde DS, Dingemans AC, Verheul HM, et al. Exploration of the Platelet Proteome in Patients With Early-Stage Cancer. J Proteomics (2018) 177:65-74. doi: 10.1016/j.jprot.2018.02.011

88. Sabrkhany S, Kuijpers MJ, Verheul HM, Griffioen AW, Oude EM. Platelets: An Unexploited Data Source in Biomarker Research. Lancet Haematol (2015) 2(12):e512-3. doi: 10.1016/S2352-3026(15)00225-2

89. Lomnytska M, Pinto R, Becker S, Engstrom U, Gustafsson S, Bjorklund C, et al. Platelet Protein Biomarker Panel for Ovarian Cancer Diagnosis. biomark Res (2018) 6:2. doi: 10.1186/s40364-018-0118-y

90. Honda K. The Biological Role of Actinin-4 (ACTN4) in Malignant Phenotypes of Cancer. Cell Biosci (2015) 5:41. doi: 10.1186/s13578-0150031-0

91. Haslene-Hox H, Oveland E, Woie K, Salvesen HB, Wiig H, Tenstad O. Increased WD-Repeat Containing Protein 1 in Interstitial Fluid From Ovarian Carcinomas Shown by Comparative Proteomic Analysis of Malignant and Healthy Gynecological Tissue. Biochim Biophys Acta (2013) 1834(11):2347-59. doi: 10.1016/j.bbapap.2013.05.011 
92. Tang H, Yao L, Tao X, Yu Y, Chen M, Zhang R, et al. miR-9 Functions as a Tumor Suppressor in Ovarian Serous Carcinoma by Targeting TLN1. Int $J$ Mol Med (2013) 32(2):381-8. doi: 10.3892/ijmm.2013.1400

93. Heijnen HF, Debili N, Vainchencker W, Breton-Gorius J, Geuze HJ, Sixma JJ. Multivesicular Bodies Are an Intermediate Stage in the Formation of Platelet Alpha-Granules. Blood (1998) 91(7):2313-25. doi: 10.1182/ blood.V91.7.2313

94. Anderson KS, Sibani S, Wallstrom G, Qiu J, Mendoza EA, Raphael J, et al. Protein Microarray Signature of Autoantibody Biomarkers for the Early Detection of Breast Cancer. J Proteome Res (2011) 10(1):85-96. doi: 10.1021/ pr100686b

95. Zucchella M, Dezza L, Pacchiarini L, Meloni F, Tacconi F, Bonomi E, et al. Human Tumor Cells Cultured "In Vitro" Activate Platelet Function by Producing ADP or Thrombin. Haematologica (1989) 74(6):541-5.

96. Boukerche H, Berthier-Vergnes O, Penin F, Tabone E, Lizard G, Bailly M, et al. Human Melanoma Cell Lines Differ in Their Capacity to Release ADP and Aggregate Platelets. Br J Haematol (1994) 87(4):763-72. doi: 10.1111/ j.1365-2141.1994.tb06736.x

97. Steinert BW, Tang DG, Grossi IM, Umbarger LA, Honn KV. Studies on the Role of Platelet Eicosanoid Metabolism and Integrin Alpha IIb Beta 3 in Tumor-Cell-Induced Platelet Aggregation. Int J Cancer (1993) 54(1):92-101. doi: 10.1002/ijc.2910540116

98. Mitrugno A, Tormoen GW, Kuhn P, McCarty OJ. The Prothrombotic Activity of Cancer Cells in the Circulation. Blood Rev (2016) 30(1):11-9. doi: 10.1016/j.blre.2015.07.001

99. Heinmoller E, Weinel RJ, Heidtmann HH, Salge U, Seitz R, Schmitz I, et al. Studies on Tumor-Cell-Induced Platelet Aggregation in Human Lung Cancer Cell Lines. J Cancer Res Clin Oncol (1996) 122(12):735-44. doi: 10.1007/BF01209121

100. Sternlicht MD, Werb Z. How Matrix Metalloproteinases Regulate Cell Behavior. Annu Rev Cell Dev Biol (2001) 17:463-516. doi: 10.1146/ annurev.cellbio.17.1.463

101. Ko HM, Park YM, Jung B, Kim HA, Choi JH, Park SJ, et al. Involvement of Matrix Metalloproteinase-9 in Platelet-Activating Factor-Induced Angiogenesis. FEBS Lett (2005) 579(11):2369-75. doi: 10.1016/j.febslet. 2005.03.035

102. Alonso-Escolano D, Strongin AY, Chung AW, Deryugina EI, Radomski MW. Membrane Type-1 Matrix Metalloproteinase Stimulates Tumour CellInduced Plateletaggregation: Role of Receptor Glycoproteins. Br J Pharmacol (2004) 141(2):241-52. doi: 10.1038/sj.bjp.0705606

103. Mitrugno A, Williams D, Kerrigan SW, Moran N. A Novel and Essential Role for FcgammaRIIa in Cancer Cell-Induced Platelet Activation. Blood (2014) 123(2):249-60. doi: 10.1182/blood-2013-03-492447

104. Callander NS, Varki N, Rao LV. Immunohistochemical Identification of Tissue Factor in Solid Tumors. Cancer-Am Cancer Soc (1992) 70(5):1194201. doi: 10.1002/1097-0142(19920901)70:5<1194::AID-CNCR2820700528> 3.0.CO;2-E

105. Yu JL, May L, Lhotak V, Shahrzad S, Shirasawa S, Weitz JI, et al. Oncogenic Events Regulate Tissue Factor Expression in Colorectal Cancer Cells: Implications for Tumor Progression and Angiogenesis. Blood (2005) 105 (4):1734-41. doi: 10.1182/blood-2004-05-2042

106. Rong Y, Post DE, Pieper RO, Durden DL, Van Meir EG, Brat DJ. PTEN and Hypoxia Regulate Tissue Factor Expression and Plasma Coagulation by Glioblastoma. Cancer Res (2005) 65(4):1406-13. doi: 10.1158/00085472.CAN-04-3376

107. Gomes FG, Sandim V, Almeida VH, Rondon A, Succar BB, Hottz ED, et al. Breast-Cancer Extracellular Vesicles Induce Platelet Activation and Aggregation by Tissue Factor-Independent and -Dependent Mechanisms. Thromb Res (2017) 159:24-32. doi: 10.1016/j.thromres.2017.09.019

108. Orellana R, Kato S, Erices R, Bravo ML, Gonzalez P, Oliva B, et al. Platelets Enhance Tissue Factor Protein and Metastasis Initiating Cell Markers, and Act as Chemoattractants Increasing the Migration of Ovarian Cancer Cells. BMC Cancer (2015) 15:290. doi: 10.1186/s12885015-1304-z

109. Yu LX, Yan L, Yang W, Wu FQ, Ling Y, Chen SZ, et al. Platelets Promote Tumour Metastasis via Interaction Between TLR4 and Tumour CellReleased High-Mobility Group Box1 Protein. Nat Commun (2014) 5:5256. doi: $10.1038 /$ ncomms6256
110. Jaspars LH, Vos W, Aust G, Van Lier RA, Hamann J. Tissue Distribution of the Human CD97 EGF-TM7 Receptor. Tissue Antigens (2001) 57(4):325-31. doi: 10.1034/j.1399-0039.2001.057004325.x

111. Aust G, Steinert M, Schutz A, Boltze C, Wahlbuhl M, Hamann J, et al. CD97, But Not Its Closely Related EGF-TM7 Family Member EMR2, Is Expressed on Gastric, Pancreatic, and Esophageal Carcinomas. Am J Clin Pathol (2002) 118(5):699-707. doi: 10.1309/A6AB-VF3F-7M88-C0EJ

112. Steinert M, Wobus M, Boltze C, Schutz A, Wahlbuhl M, Hamann J, et al. Expression and Regulation of CD97 in Colorectal Carcinoma Cell Lines and Tumor Tissues. Am J Pathol (2002) 161(5):1657-67. doi: 10.1016/S00029440(10)64443-4

113. Ward Y, Lake R, Faraji F, Sperger J, Martin P, Gilliard C, et al. Platelets Promote Metastasis via Binding Tumor CD97 Leading to Bidirectional Signaling That Coordinates Transendothelial Migration. Cell Rep (2018) 23 (3):808-22. doi: 10.1016/j.celrep.2018.03.092

114. Lee G, Cheung AP, Li B, Ge B, Chow PM. Molecular and ImmunoCharacteristics of Immunoglobulin-Like Glycoproteins in Cancer CellExpressed Biomarker, CA215. Immunol Invest (2012) 41(4):429-46. doi: $10.3109 / 08820139.2012 .661007$

115. Zheng J, Huang J, Mao Y, Liu S, Sun X, Zhu X, et al. Immunoglobulin Gene Transcripts Have Distinct VHDJH Recombination Characteristics in Human Epithelial Cancer Cells. J Biol Chem (2009) 284(20):13610-9. doi: 10.1074/ jbc.M809524200

116. Zhu X, Wu L, Zhang L, Hao P, Zhang S, Huang J, et al. Distinct Regulatory Mechanism of Immunoglobulin Gene Transcription in Epithelialcancer Cells. Cell Mol Immunol (2010) 7(4):279-86. doi: 10.1038/cmi.2010.13

117. Liao Q, Liu W, Liu Y, Wang F, Wang C, Zhang J, et al. Aberrant High Expression of Immunoglobulin G in Epithelial Stem/Progenitor-Like Cells Contributes to Tumor Initiation and Metastasis. Oncotarget (2015) 6 (37):40081-94. doi: 10.18632/oncotarget.5542

118. Wang J, Lin D, Peng H, Huang Y, Huang J, Gu J. Cancer-Derived Immunoglobulin G Promotes Tumor Cell Growth and Proliferation Through Inducing Production of Reactive Oxygen Species. Cell Death Dis (2013) 4:e945. doi: 10.1038/cddis.2013.474

119. Miao S, Shu D, Zhu Y, Lu M, Zhang Q, Pei Y, et al. Cancer Cell-Derived Immunoglobulin G Activates Platelets by Binding to Platelet FcgammaRIIa. Cell Death Dis (2019) 10(2):87. doi: 10.1038/s41419-019-1367-x

120. Suzuki-Inoue K, Kato Y, Inoue O, Kaneko MK, Mishima K, Yatomi Y, et al. Involvement of the Snake Toxin Receptor CLEC-2, in Podoplanin-Mediated Platelet Activation, by Cancer Cells. J Biol Chem (2007) 282(36):25993-6001. doi: 10.1074/jbc.M702327200

121. Suzuki-Inoue K. Platelets and Cancer-Associated Thrombosis: Focusing on the Platelet Activation Receptor CLEC-2 and Podoplanin. Blood (2019) 134 (22):1912-8. doi: 10.1182/blood.2019001388

122. Wang X, Liu B, Xu M, Jiang Y, Zhou J, Yang J, et al. Blocking Podoplanin Inhibits Platelet Activation and Decreases Cancer-Associatedvenous Thrombosis. Thromb Res (2021) 200:72-80. doi: 10.1016/j.thromres.2021. 01.008

123. Ponert JM, Schwarz S, Haschemi R, Muller J, Potzsch B, Bendas G, et al. The Mechanisms How Heparin Affects the Tumor Cell Induced VEGF and Chemokine Release From Platelets to Attenuate the Early Metastatic Niche Formation. PloS One (2018) 13(1):e0191303. doi: 10.1371/journal.pone. 0191303

124. Labelle M, Begum S, Hynes RO. Platelets Guide the Formation of Early Metastatic Niches. Proc Natl Acad Sci USA (2014) 111(30):E3053-61. doi: $10.1073 /$ pnas.1411082111

125. Lucotti S, Muschel RJ. Platelets and Metastasis: New Implications of an Old Interplay. Front Oncol (2020) 10:1350. doi: 10.3389/fonc.2020. 01350

126. Fuchs TA, Brill A, Duerschmied D, Schatzberg D, Monestier M, Myers DJ, et al. Extracellular DNA Traps Promote Thrombosis. Proc Natl Acad Sci USA (2010) 107(36):15880-5. doi: 10.1073/pnas.1005743107

127. Demers M, Krause DS, Schatzberg D, Martinod K, Voorhees JR, Fuchs TA, et al. Cancers Predispose Neutrophils to Release Extracellular DNA Traps That Contribute to Cancer-Associated Thrombosis. Proc Natl Acad Sci USA (2012) 109(32):13076-81. doi: 10.1073/pnas.1200419109

128. Abdol RN, Elaskalani O, Metharom P. Pancreatic Cancer-Induced Neutrophil Extracellular Traps: A Potential Contributor to Cancer- 
Associated Thrombosis. Int J Mol Sci (2017) 18(3):487. doi: 10.3390/ ijms 18030487

129. Semeraro F, Ammollo CT, Morrissey JH, Dale GL, Friese P, Esmon NL, et al. Extracellular Histones Promote Thrombin Generation Through PlateletDependent Mechanisms: Involvement of Platelet TLR2 and TLR4. Blood (2011) 118(7):1952-61. doi: 10.1182/blood-2011-03-343061

130. Gomez RM, Lopez OA, Schattner M. Platelets and Extracellular Traps in Infections. Platelets (2021) 32(3):305-13. doi: 10.1080/09537104.2020. 1718631

131. Lam FW, Cruz MA, Parikh K, Rumbaut RE. Histones Stimulate Von Willebrand Factor Release In Vitro and In Vivo. Haematologica (2016) 101 (7):e277-9. doi: 10.3324/haematol.2015.140632

132. Colucci M, Balconi G, Lorenzet R, Pietra A, Locati D, Donati MB, et al. Cultured Human Endothelial Cells Generate Tissue Factor in Response to Endotoxin. J Clin Invest (1983) 71(6):1893-6. doi: 10.1172/jci110945

133. Bevilacqua MP, Pober JS, Majeau GR, Fiers W, Cotran RS, Gimbrone MJ. Recombinant Tumor Necrosis Factor Induces Procoagulant Activity in Cultured Human Vascular Endothelium: Characterization and Comparison With the Actions of Interleukin 1. Proc Natl Acad Sci USA (1986) 83(12):4533-7. doi: 10.1073/pnas.83.12.4533

134. Li N. Platelets in Cancer Metastasis: To Help the "Villain" to do Evil. Int $J$ Cancer (2016) 138(9):2078-87. doi: 10.1002/ijc.29847

135. Cho MS, Bottsford-Miller J, Vasquez HG, Stone R, Zand B, Kroll MH, et al. Platelets Increase the Proliferation of Ovarian Cancer Cells. Blood (2012) 120 (24):4869-72. doi: 10.1182/blood-2012-06-438598

136. Hu Q, Hisamatsu T, Haemmerle M, Cho MS, Pradeep S, Rupaimoole R, et al. Role of Platelet-Derived Tgfbetal in the Progression of Ovarian Cancer. Clin Cancer Res (2017) 23(18):5611-21. doi: 10.1158/1078-0432.CCR16-3272

137. Qi C, Wei B, Zhou W, Yang Y, Li B, Guo S, et al. P-Selectin-Mediated Platelet Adhesion Promotes Tumor Growth. Oncotarget (2015) 6(9):6584-96. doi: 10.18632/oncotarget.3164

138. Jiang L, Luan Y, Miao X, Sun C, Li K, Huang Z, et al. Platelet Releasate Promotes Breast Cancer Growth and Angiogenesis via VEGF-Integrin Cooperative Signalling. Br J Cancer (2017) 117(5):695-703. doi: 10.1038/ bjc.2017.214

139. Pucci F, Rickelt S, Newton AP, Garris C, Nunes E, Evavold C, et al. PF4 Promotes Platelet Production and Lung Cancer Growth. Cell Rep (2016) 17 (7):1764-72. doi: 10.1016/j.celrep.2016.10.031

140. Takagi S, Sato S, Oh-hara T, Takami M, Koike S, Mishima Y, et al. Platelets Promote Tumor Growth and Metastasis via Direct Interaction Between Aggrus/podoplanin and CLEC-2. PloS One (2013) 8(8):e73609. doi: 10.1371/ journal.pone. 0073609

141. Cho MS, Noh K, Haemmerle M, Li D, Park H, Hu Q, et al. Role of ADP Receptors on Platelets in the Growth of Ovarian Cancer. Blood (2017) 130 (10):1235-42. doi: 10.1182/blood-2017-02-769893

142. Pavlovic N, Kopsida M, Gerwins P, Heindryckx F. Activated Platelets Contribute to the Progression of Hepatocellular Carcinoma Byaltering the Tumor Environment. Life Sci (2021) 277:119612. doi: 10.1016/j.lfs. 2021.119612

143. Chaffer CL, Weinberg RA. A Perspective on Cancer Cell Metastasis. Science (2011) 331(6024):1559-64. doi: 10.1126/science.1203543

144. Valastyan S, Weinberg RA. Tumor Metastasis: Molecular Insights and Evolving Paradigms. Cell (2011) 147(2):275-92. doi: 10.1016/j.cell. 2011.09.024

145. Saito R, Shoda K, Maruyama S, Yamamoto A, Takiguchi K, Furuya S, et al. Platelets Enhance Malignant Behaviours of Gastric Cancer Cells via Direct Contacts. Br J Cancer (2021) 124(3):570-3. doi: 10.1038/s41416-02001134-7

146. Ren J, He J, Zhang H, Xia Y, Hu Z, Loughran P, et al. Platelet TLR4-ERK5 Axis Facilitates NET-Mediated Capturing of Circulating Tumor Cells and Distant Metastasis After Surgical Stress. Cancer Res (2021) 81(9):2373-85. doi: 10.1158/0008-5472.CAN-20-3222

147. Gasic GJ, Gasic TB, Stewart CC. Antimetastatic Effects Associated With Platelet Reduction. Proc Natl Acad Sci USA (1968) 61(1):46-52. doi: 10.1073/ pnas.61.1.46

148. Gay LJ, Felding-Habermann B. Contribution of Platelets to Tumour Metastasis. Nat Rev Cancer (2011) 11(2):123-34. doi: 10.1038/nrc3004
149. Wang JD, Wang YY, Lin SY, Chang CY, Li JR, Huang SW, et al. Exosomal HMGB1 Promoted Cancer Malignancy. Cancers (Basel) (2021) 13(4):877. doi: 10.3390/cancers 13040877

150. Vismara M, Zara M, Negri S, Canino J, Canobbio I, Barbieri SS, et al. PlateletDerived Extracellular Vesicles Regulate Cell Cycle Progression and Cellmigration in Breast Cancer Cells. Biochim Biophys Acta Mol Cell Res (2021) 1868(1):118886. doi: 10.1016/j.bbamcr.2020.118886

151. Rudzinski JK, Govindasamy NP, Asgari A, Saito MS, Lewis JD, Jurasz P. Preferential Interaction of Platelets With Prostate Cancer Cells With Stem Cell Markers. Thromb Res (2021) 206:42-51. doi: 10.1016/j.thromres. 2021.08.008

152. Dubrovska A, Elliott J, Salamone RJ, Telegeev GD, Stakhovsky AE, Schepotin IB, et al. CXCR4 Expression in Prostate Cancer Progenitor Cells. PloS One (2012) 7(2):e31226. doi: 10.1371/journal.pone.0031226

153. Scheel C, Onder T, Karnoub A, Weinberg RA. Adaptation Versus Selection: The Origins of Metastatic Behavior. Cancer Res (2007) 67(24):11476-9; discussion 11479-80. doi: 10.1158/0008-5472.CAN-07-1653

154. Guo Y, Cui W, Pei Y, Xu D. Platelets Promote Invasion and Induce Epithelial to Mesenchymal Transition in Ovarian Cancer Cells by TGF-Beta Signaling Pathway. Gynecol Oncol (2019) 153(3):639-50. doi: 10.1016/j.ygyno.2019. 02.026

155. Marcolino E, Siddiqui YH, van den Bosch M, Poole AW, Jayaraman PS, Gaston K. Blood Platelets Stimulate Cancer Extravasation Through TGFbeta-Mediated Downregulation of PRH/HHEX. Oncogenesis (2020) 9 (2):10. doi: 10.1038/s41389-020-0189-0

156. Labelle M, Begum S, Hynes RO. Direct Signaling Between Platelets and Cancer Cells Induces an Epithelial-Mesenchymal-Like Transition and Promotes Metastasis. Cancer Cell (2011) 20(5):576-90. doi: 10.1016/ j.ccr.2011.09.009

157. Zhang Y, Unnithan R, Hamidi A, Caja L, Saupe F, Moustakas A, et al. TANK-Binding Kinase 1 Is a Mediator of Platelet-Induced EMT in Mammary Carcinomacells. FASEB J (2019) 33(7):7822-32. doi: 10.1096/ fj.201801936RRR

158. Fujita N, Takagi S. The Impact of Aggrus/podoplanin on Platelet Aggregation and Tumour Metastasis. J Biochem (2012) 152(5):407-13. doi: $10.1093 / \mathrm{jb} / \mathrm{mvs} 108$

159. Takemoto A, Okitaka M, Takagi S, Takami M, Sato S, Nishio M, et al. A Critical Role of Platelet TGF-Beta Release in Podoplanin-Mediated Tumour Invasion and Metastasis. Sci Rep (2017) 7:42186. doi: 10.1038/srep42186

160. Zuo XX, Yang Y, Zhang Y, Zhang ZG, Wang XF, Shi YG. Platelets Promote Breast Cancer Cell MCF-7 Metastasis by Direct Interaction: Surface Integrin Alpha2beta1-Contacting-Mediated Activation of Wnt-Beta-Catenin Pathway. Cell Commun Signal (2019) 17(1):142. doi: 10.1186/s12964-0190464-x

161. Radziwon-Balicka A, Santos-Martinez MJ, Corbalan JJ, O’Sullivan S, Treumann A, Gilmer JF, et al. Mechanisms of Platelet-Stimulated Colon Cancer Invasion: Role of Clusterin and Thrombospondin 1 in Regulation of the P38MAPK-MMP-9 Pathway. Carcinogenesis (2014) 35(2):324-32. doi: $10.1093 /$ carcin/bgt332

162. Weber MR, Zuka M, Lorger M, Tschan M, Torbett BE, Zijlstra A, et al. Activated Tumor Cell Integrin Alphavbeta3 Cooperates With Platelets to Promote Extravasation and Metastasis From the Blood Stream. Thromb Res (2016) 140 Suppl:1, S27-36. doi: 10.1016/S0049-3848(16)30095-0

163. Johnson KE, Ceglowski JR, Roweth HG, Forward JA, Tippy MD, El-Husayni S, et al. Aspirin Inhibits Platelets From Reprogramming Breast Tumor Cells and Promoting Metastasis. Blood Adv (2019) 3(2):198-211. doi: 10.1182/ bloodadvances.2018026161

164. Wang W, Chu HY, Zhong ZM, Qi X, Cheng R, Qin RJ, et al. Platelet-Secreted CCL3 and Its Receptor CCR5 Promote Invasive and Migratory Abilities of Anaplastic Thyroid Carcinoma Cells via MMP-1. Cell Signal (2019) 63:109363. doi: 10.1016/j.cellsig.2019.109363

165. Oda SK, Strauch P, Fujiwara Y, Al-Shami A, Oravecz T, Tigyi G, et al. Lysophosphatidic Acid Inhibits CD8 T Cell Activation and Control of Tumor Progression. Cancer Immunol Res (2013) 1(4):245-55. doi: 10.1158/2326-6066.CIR-13-0043-T

166. Leblanc R, Houssin A, Peyruchaud O. Platelets, Autotaxin and Lysophosphatidic Acid Signalling: Win-Win Factors for Cancer Metastasis. Br J Pharmacol (2018) 175(15):3100-10. doi: 10.1111/bph.14362 
167. Leblanc R, Lee SC, David M, Bordet JC, Norman DD, Patil R, et al. Interaction of Platelet-Derived Autotaxin With Tumor Integrin Alphavbeta3 Controls Metastasis of Breast Cancer Cells to Bone. Blood (2014) 124(20):3141-50. doi: 10.1182/blood-2014-04-568683

168. Fang X, Yu S, Bast RC, Liu S, Xu HJ, Hu SX, et al. Mechanisms for Lysophosphatidic Acid-Induced Cytokine Production in Ovarian Cancer Cells. J Biol Chem (2004) 279(10):9653-61. doi: 10.1074/jbc.M306662200

169. Boucharaba A, Serre CM, Gres S, Saulnier-Blache JS, Bordet JC, Guglielmi J, et al. Platelet-Derived Lysophosphatidic Acid Supports the Progression of Osteolytic Bone Metastases in Breast Cancer. J Clin Invest (2004) 114 (12):1714-25. doi: 10.1172/JCI22123

170. Umezu-Goto M, Kishi Y, Taira A, Hama K, Dohmae N, Takio K, et al. Autotaxin has Lysophospholipase D Activity Leading to Tumor Cell Growth and Motility by Lysophosphatidic Acid Production. J Cell Biol (2002) 158 (2):227-33. doi: 10.1083/jcb.200204026

171. Federico L, Jeong KJ, Vellano CP, Mills GB. Autotaxin, a Lysophospholipase D With Pleomorphic Effects in Oncogenesis and Cancer Progression. J Lipid Res (2016) 57(1):25-35. doi: 10.1194/jlr.R060020

172. Xu XR, Carrim N, Neves MA, McKeown T, Stratton TW, Coelho RM, et al. Platelets and Platelet Adhesion Molecules: Novel Mechanisms of Thrombosis and Anti-Thrombotic Therapies. Thromb J (2016) 14(Suppl 1):29. doi: 10.1186/s12959-016-0100-6

173. Schwarz S, Gockel LM, Naggi A, Barash U, Gobec M, Bendas G, et al. Glycosaminoglycans as Tools to Decipher the Platelet Tumor Cell Interaction: A Focus on P-Selectin. Molecules (2020) 25(5):1039. doi: 10.3390/molecules25051039

174. Anvari S, Osei E, Maftoon N. Interactions of Platelets With Circulating Tumor Cells Contribute to Cancer Metastasis. Sci Rep (2021) 11(1):15477. doi: 10.1038/s41598-021-94735-y

175. Schlesinger M. Role of Platelets and Platelet Receptors in Cancer Metastasis. J Hematol Oncol (2018) 11(1):125. doi: 10.1186/s13045-018-0669-2

176. Kim YJ, Borsig L, Han HL, Varki NM, Varki A. Distinct Selectin Ligands on Colon Carcinoma Mucins Can Mediate Pathological Interactions Among Platelets, Leukocytes, and Endothelium. Am J Pathol (1999) 155(2):461-72. doi: 10.1016/S0002-9440(10)65142-5

177. Coupland LA, Chong BH, Parish CR. Platelets and P-Selectin Control Tumor Cell Metastasis in an Organ-Specific Manner and Independently of NK Cells. Cancer Res (2012) 72(18):4662-71. doi: 10.1158/0008-5472.CAN11-4010

178. Nolo R, Herbrich S, Rao A, Zweidler-McKay P, Kannan S, Gopalakrishnan V. Targeting P-Selectin Blocks Neuroblastoma Growth. Oncotarget (2017) 8 (49):86657-70. doi: 10.18632/oncotarget.21364

179. Mammadova-Bach E, Zigrino P, Brucker C, Bourdon C, Freund M, De Arcangelis A, et al. Platelet Integrin Alpha6betal Controls Lung Metastasis Through Direct Binding Tocancer Cell-Derived ADAM9. JCI Insight (2016) 1(14):e88245. doi: 10.1172/jci.insight. 88245

180. Jain S, Russell S, Ware J. Platelet Glycoprotein VI Facilitates Experimental Lung Metastasis in Syngenic Mouse Models. J Thromb Haemost (2009) 7 (10):1713-7. doi: 10.1111/j.1538-7836.2009.03559.x

181. Mammadova-Bach E, Gil-Pulido J, Sarukhanyan E, Burkard P, Shityakov S, Schonhart C, et al. Platelet Glycoprotein VI Promotes Metastasis Through Interaction With Cancer Cell-Derived Galectin-3. Blood (2020) 135 (14):1146-60. doi: 10.1182/blood.2019002649

182. Janowska-Wieczorek A, Wysoczynski M, Kijowski J, Marquez-Curtis L, Machalinski B, Ratajczak J, et al. Microvesicles Derived From Activated Platelets Induce Metastasis and Angiogenesis in Lung Cancer. Int J Cancer (2005) 113(5):752-60. doi: 10.1002/ijc.20657

183. Folkman J. Angiogenesis in Cancer, Vascular, Rheumatoid and Other Disease. Nat Med (1995) 1(1):27-31. doi: 10.1038/nm0195-27

184. Kisucka J, Butterfield CE, Duda DG, Eichenberger SC, Saffaripour S, Ware J, et al. Platelets and Platelet Adhesion Support Angiogenesis While Preventing Excessive Hemorrhage. Proc Natl Acad Sci USA (2006) 103(4):855-60. doi: $10.1073 /$ pnas.0510412103

185. Wojtukiewicz MZ, Sierko E, Hempel D, Tucker SC, Honn KV. Platelets and Cancer Angiogenesis Nexus. Cancer Metastasis Rev (2017) 36(2):249-62. doi: 10.1007/s10555-017-9673-1

186. Sierko E, Wojtukiewicz MZ. Platelets and Angiogenesis in Malignancy. Semin Thromb Hemost (2004) 30(1):95-108. doi: 10.1055/s-2004-822974
187. Battinelli EM, Markens BA, Italiano JJ. Release of Angiogenesis Regulatory Proteins From Platelet Alpha Granules: Modulation of Physiologic and Pathologic Angiogenesis. Blood (2011) 118(5):1359-69. doi: 10.1182/blood2011-02-334524

188. Huang Z, Miao X, Luan Y, Zhu L, Kong F, Lu Q, et al. PAR1-Stimulated Platelet Releasate Promotes Angiogenic Activities of Endothelialprogenitor Cells More Potently Than PAR4-Stimulated Platelet Releasate. J Thromb Haemost (2015) 13(3):465-76. doi: 10.1111/jth.12815

189. Tsopanoglou NE, Maragoudakis ME. Thrombin's Central Role in Angiogenesis and Pathophysiological Processes. Eur Cytokine Netw (2009) 20(4):171-9. doi: 10.1684/ecn.2009.0166

190. Wojtukiewicz MZ, Hempel D, Sierko E, Tucker SC, Honn KV. ThrombinUnique Coagulation System Protein With Multifaceted Impacts on Cancer and Metastasis. Cancer Metastasis Rev (2016) 35(2):213-33. doi: 10.1007/ s10555-016-9626-0

191. McDowell G, Temple I, Li C, Kirwan CC, Bundred NJ, McCollum CN, et al. Alteration in Platelet Function in Patients With Early Breast Cancer. Anticancer Res (2005) 25(6B):3963-6. doi: 10.1016/j.cej.2007.07.090

192. Battinelli EM, Markens BA, Kulenthirarajan RA, Machlus KR, Flaumenhaft R, Italiano JJ. Anticoagulation Inhibits Tumor Cell-Mediated Release of Platelet Angiogenic Proteins and Diminishes Platelet Angiogenic Response. Blood (2014) 123(1):101-12. doi: 10.1182/blood-2013-02-485011

193. Bambace NM, Levis JE, Holmes CE. The Effect of P2Y-Mediated Platelet Activation on the Release of VEGF and Endostatin From Platelets. Platelets (2010) 21(2):85-93. doi: 10.3109/09537100903470298

194. Volz J, Mammadova-Bach E, Gil-Pulido J, Nandigama R, Remer K, Sorokin $\mathrm{L}$, et al. Inhibition of Platelet GPVI Induces Intratumor Hemorrhage and Increases Efficacyof Chemotherapy in Mice. Blood (2019) 133(25):2696-706. doi: 10.1182/blood.2018877043

195. Kim HK, Song KS, Chung JH, Lee KR, Lee SN. Platelet Microparticles Induce Angiogenesis. Vitro Br J Haematol (2004) 124(3):376-84. doi: 10.1046/ j.1365-2141.2003.04773.x

196. Brill A, Dashevsky O, Rivo J, Gozal Y, Varon D. Platelet-Derived Microparticles Induce Angiogenesis and Stimulate Post-Ischemic Revascularization. Cardiovasc Res (2005) 67(1):30-8. doi: 10.1016/ j.cardiores.2005.04.007

197. Starlinger P, Moll HP, Assinger A, Nemeth C, Hoetzenecker K, Gruenberger B, et al. Thrombospondin-1: A Unique Marker to Identify In Vitro Platelet Activation When Monitoring In Vivo Processes. J Thromb Haemost (2010) 8 (8):1809-19. doi: 10.1111/j.1538-7836.2010.03908.x

198. Han X, Guo B, Li Y, Zhu B. Tissue Factor in Tumor Microenvironment: A Systematic Review. J Hematol Oncol (2014) 7:54. doi: 10.1186/s13045-0140054-8

199. Mezouar S, Frere C, Darbousset R, Mege D, Crescence L, Dignat-George F, et al. Role of Platelets in Cancer and Cancer-Associated Thrombosis: Experimental and Clinical Evidences. Thromb Res (2016) 139:65-76. doi: 10.1016/j.thromres.2016.01.006

200. Jurasz P, Alonso-Escolano D, Radomski MW. Platelet-cancer Interactions: Mechanisms and Pharmacology of Tumour Cell-Induced Platelet Aggregation. Br J Pharmacol (2004) 143(7):819-26. doi: 10.1038/ sj.bjp.0706013

201. Karpatkin S, Ambrogio C, Pearlstein E. The Role of Tumor-Induced Platelet Aggregation, Platelet Adhesion and Adhesive Proteins in Tumor Metastasis. Prog Clin Biol Res (1988) 283:585-606. doi: 10.4271/2004-01-2819

202. Zara M, Canobbio I, Visconte C, Canino J, Torti M, Guidetti GF. Molecular Mechanisms of Platelet Activation and Aggregation Induced by Breast Cancer Cells. Cell Signal (2018) 48:45-53. doi: 10.1016/j.cellsig.2018.04.008

203. Okazaki M, Yamaguchi T, Tajima H, Fushida S, Ohta T. Platelet Adherence to Cancer Cells Promotes Escape From Innate Immune Surveillance in Cancer Metastasis. Int J Oncol (2020) 57(4):980-8. doi: 10.3892/ ijo.2020.5102

204. Shimaoka H, Takeno S, Maki K, Sasaki T, Hasegawa S, Yamashita Y. A Cytokine Signal Inhibitor for Rheumatoid Arthritis Enhances Cancer Metastasis via Depletion of NK Cells in an Experimental Lung Metastasis Mouse Model of Colon Cancer. Oncol Lett (2017) 14(3):3019-27. doi: 10.3892/ol.2017.6473

205. Placke T, Orgel M, Schaller M, Jung G, Rammensee HG, Kopp HG, et al. Platelet-Derived MHC Class I Confers a Pseudonormal Phenotype to Cancer 
Cells That Subverts the Antitumor Reactivity of Natural Killer Immune Cells. Cancer Res (2012) 72(2):440-8. doi: 10.1158/0008-5472.CAN-11-1872

206. Kopp HG, Placke T, Salih HR. Platelet-Derived Transforming Growth Factor-Beta Down-Regulates NKG2D Thereby Inhibiting Natural Killer Cell Antitumor Reactivity. Cancer Res (2009) 69(19):7775-83. doi: 10.1158/0008-5472.CAN-09-2123

207. Sadallah S, Schmied L, Eken C, Charoudeh HN, Amicarella F, Schifferli JA. Platelet-Derived Ectosomes Reduce NK Cell Function. J Immunol (2016) 197 (5):1663-71. doi: 10.4049/jimmunol.1502658

208. Donatelli SS, Zhou JM, Gilvary DL, Eksioglu EA, Chen X, Cress WD, et al. TGF-Beta-Inducible microRNA-183 Silences Tumor-Associated Natural Killer Cells. Proc Natl Acad Sci USA (2014) 111(11):4203-8. doi: 10.1073/ pnas.1319269111

209. Haribhai D, Luo X, Chen J, Jia S, Shi L, Schroeder JA, et al. TGF-Betal Along With Other Platelet Contents Augments Treg Cells to Suppress Anti-FVIII Immune Responses in Hemophilia A Mice. Blood Adv (2016) 1(2):139-51. doi: 10.1182/bloodadvances.2016001453

210. Rachidi S, Metelli A, Riesenberg B, Wu BX, Nelson MH, Wallace C, et al. Platelets Subvert T Cell Immunity Against Cancer via GARP-TGFbeta Axis. Sci Immunol (2017) 2(11):eaai7911. doi: 10.1126/sciimmunol.aai7911

211. Polasky C, Wendt F, Pries R, Wollenberg B. Platelet Induced Functional Alteration of CD4(+) and CD8(+) T Cells in HNSCC. Int J Mol Sci (2020) 21 (20):7507. doi: 10.3390/ijms21207507

212. Zaslavsky AB, Adams MP, Cao X, Maj T, Choi JE, Stangl-Kremser J, et al. Platelet PD-L1 Suppresses Anti-Cancer Immune Cell Activity in PD-L1 Negative Tumors. Sci Rep (2020) 10(1):19296. doi: 10.1038/s41598-02076351-4

213. Cluxton CD, Spillane C, O’Toole SA, Sheils O, Gardiner CM, O'Leary JJ. Suppression of Natural Killer Cell NKG2D and CD226 Anti-Tumour Cascades by Platelet Cloaked Cancer Cells: Implications for the Metastatic Cascade. PloS One (2019) 14(3):e0211538. doi: 10.1371/journal.pone. 0211538

214. Maurer S, Kopp HG, Salih HR, Kropp KN. Modulation of Immune Responses by Platelet-Derived Adam10. Front Immunol (2020) 11:44. doi: 10.3389/fimmu.2020.00044

215. Zhou Y, Heitmann JS, Clar KL, Kropp KN, Hinterleitner M, Engler T, et al. Platelet-Expressed Immune Checkpoint Regulator GITRL in Breast Cancer. Cancer Immunol Immunother (2021) 70(9):2483-96. doi: 10.1007/s00262021-02866-y

216. Clar KL, Hinterleitner C, Schneider P, Salih HR, Maurer S. Inhibition of NK Reactivity Against Solid Tumors by Platelet-Derived RANKL. Cancers (Basel) (2019) 11(3):277. doi: 10.3390/cancers11030277

217. Placke T, Salih HR, Kopp HG. GITR Ligand Provided by Thrombopoietic Cells Inhibits NK Cell Antitumor Activity. J Immunol (2012) 189(1):154-60. doi: 10.4049/jimmunol.1103194

218. Haemmerle M, Taylor ML, Gutschner T, Pradeep S, Cho MS, Sheng J, et al. Platelets Reduce Anoikis and Promote Metastasis by Activating YAP1 Signaling. Nat Commun (2017) 8(1):310. doi: 10.1038/s41467-017-00411-z

219. Romashkova JA, Makarov SS. NF-KappaB Is a Target of AKT in AntiApoptotic PDGF Signalling. Nature (1999) 401(6748):86-90. doi: 10.1038/ 43474

220. Li T, Guo T, Liu H, Jiang H, Wang Y. Plateletderived Growth factorBB Mediates Pancreatic Cancer Malignancy via Regulation of the Hippo/ Yesassociated Protein Signaling Pathway. Oncol Rep (2021) 45(1):83-94. doi: 10.3892/or.2020.7859

221. Naik MU, Patel P, Derstine R, Turaga R, Chen X, Golla K, et al. Ask1 Regulates Murine Platelet Granule Secretion, Thromboxane A2 Generation, Andthrombus Formation. Blood (2017) 129(9):1197-209. doi: 10.1182/ blood-2016-07-729780

222. Kamiyama M, Shirai T, Tamura S, Suzuki-Inoue K, Ehata S, Takahashi K, et al. ASK1 Facilitates Tumor Metastasis Through Phosphorylation of an ADP Receptor P2Y12 in Platelets. Cell Death Differ (2017) 24(12):2066-76. doi: 10.1038/cdd.2017.114

223. Pallero MA, Elzie CA, Chen J, Mosher DF, Murphy-Ullrich JE. Thrombospondin 1 Binding to Calreticulin-LRP1 Signals Resistance to Anoikis. FASEB J (2008) 22(11):3968-79. doi: 10.1096/fj.07-104802

224. Saito H, Fushida S, Miyashita T, Oyama K, Yamaguchi T, Tsukada T, et al. Potential of Extravasated Platelet Aggregation as a Surrogate Marker for
Overallsurvival in Patients With Advanced Gastric Cancer Treated With Preoperative Docetaxel, Cisplatin and S-1: A Retrospective Observational Study. BMC Cancer (2017) 17(1):294. doi: 10.1186/s12885-017-3279-4

225. Ishikawa S, Miyashita T, Inokuchi M, Hayashi H, Oyama K, Tajima H, et al. Platelets Surrounding Primary Tumor Cells Are Related to Chemoresistance. Oncol Rep (2016) 36(2):787-94. doi: 10.3892/or.2016.4898

226. McConkey DJ, Choi W, Marquis L, Martin F, Williams MB, Shah J, et al. Role of Epithelial-to-Mesenchymal Transition (EMT) in Drug Sensitivity and Metastasis in Bladder Cancer. Cancer Metastasis Rev (2009) 28(34):335-44. doi: 10.1007/s10555-009-9194-7

227. Zheng X, Carstens JL, Kim J, Scheible M, Kaye J, Sugimoto H, et al. Epithelial-To-Mesenchymal Transition Is Dispensable for Metastasis But Induces Chemoresistance in Pancreatic Cancer. Nature (2015) 527 (7579):525-30. doi: 10.1038/nature16064

228. Vega S, Morales AV, Ocana OH, Valdes F, Fabregat I, Nieto MA. Snail Blocks the Cell Cycle and Confers Resistance to Cell Death. Genes Dev (2004) 18(10):1131-43. doi: 10.1101/gad.294104

229. Haslehurst AM, Koti M, Dharsee M, Nuin P, Evans K, Geraci J, et al. EMT Transcription Factors Snail and Slug Directly Contribute to Cisplatin Resistance in Ovarian Cancer. BMC Cancer (2012) 12:91. doi: 10.1186/ 1471-2407-12-91

230. Chang TH, Tsai MF, Su KY, Wu SG, Huang CP, Yu SL, et al. Slug Confers Resistance to the Epidermal Growth Factor Receptor Tyrosine Kinase Inhibitor. Am J Respir Crit Care Med (2011) 183(8):1071-9. doi: 10.1164/ rccm.201009-1440OC

231. Elaskalani O, Falasca M, Moran N, Berndt MC, Metharom P. The Role of Platelet-Derived ADP and ATP in Promoting Pancreatic Cancer Cell Survival and Gemcitabine Resistance. Cancers (Basel) (2017) 9(10):142. doi: $10.3390 /$ cancers 9100142

232. Wang Z, Fang M, Li J, Yang R, Du J and Y. Luo: High Platelet Levels Attenuate the Efficacy of Platinum-Based Treatment in Non-Small Cell Lung Cancer. Cell Physiol Biochem (2018) 48(6):2456-69. doi: 10.1159/ 000492683

233. Murphy-Ullrich JE, Poczatek M. Activation of Latent TGF-Beta by Thrombospondin-1: Mechanisms and Physiology. Cytokine Growth Factor $\operatorname{Rev}(2000)$ 11(1-2):59-69. doi: 10.1016/S1359-6101(99)00029-5

234. Radziwon-Balicka A, Medina C, O’Driscoll L, Treumann A, Bazou D, Inkielewicz-Stepniak I, et al. Platelets Increase Survival of Adenocarcinoma Cells Challenged With Anticancer Drugs: Mechanisms and Implications for Chemoresistance. Br J Pharmacol (2012) 167(4):787-804. doi: 10.1111/ j.1476-5381.2012.01991.x

235. Casagrande N, Borghese C, Agostini F, Durante C, Mazzucato M, Colombatti A, et al. In Ovarian Cancer Multicellular Spheroids, Platelet Releasate Promotes Growth, Expansion of ALDH+ and CD133+ Cancer Stem Cells, and Protection Against the Cytotoxic Effects of Cisplatin, Carboplatin and Paclitaxel. Int J Mol Sci (2021) 22(6):3019. doi: 10.3390/ ijms22063019

236. Dhillon AS, Hagan S, Rath O, Kolch W. MAP Kinase Signalling Pathways in Cancer. Oncogene (2007) 26(22):3279-90. doi: 10.1038/sj.onc.1210421

237. Ma J, Cai Z, Wei H, Liu X, Zhao Q, Zhang T. The Anti-Tumor Effect of Aspirin: What We Know and What We Expect. Biomed Pharmacother (2017) 95:656-61. doi: 10.1016/j.biopha.2017.08.085

238. Rothwell PM, Wilson M, Elwin CE, Norrving B, Algra A, Warlow CP, et al. Long-Term Effect of Aspirin on Colorectal Cancer Incidence and Mortality: 20-Year Follow-Up of Five Randomised Trials. Lancet (2010) 376 (9754):1741-50. doi: 10.1016/S0140-6736(10)61543-7

239. Huang XZ, Chen Y, Wu J, Zhang X, Wu CC, Zhang CY, et al. Aspirin and Non-Steroidal Anti-Inflammatory Drugs Use Reduce Gastric Cancer Risk: A Dose-Response Meta-Analysis. Oncotarget (2017) 8(3):4781-95. doi: 10.18632/oncotarget.13591

240. Risch HA, Lu L, Streicher SA, Wang J, Zhang W, Ni Q, et al. Aspirin Use and Reduced Risk of Pancreatic Cancer. Cancer Epidemiol Biomarkers Prev (2017) 26(1):68-74. doi: 10.1158/1055-9965.EPI-16-0508

241. Choi J, Ghoz HM, Peeraphatdit T, Baichoo E, Addissie BD, Harmsen WS, et al. Aspirin Use and the Risk of Cholangiocarcinoma. Hepatology (2016) 64 (3):785-96. doi: 10.1002/hep.28529

242. Jacobs EJ, Newton CC, Stevens VL, Campbell PT, Freedland SJ, Gapstur SM. Daily Aspirin Use and Prostate Cancer-Specific Mortality in a Large Cohort 
of Men With Nonmetastatic Prostate Cancer. J Clin Oncol (2014) 32 (33):3716-22. doi: 10.1200/JCO.2013.54.8875

243. Chen WY, Holmes MD. Role of Aspirin in Breast Cancer Survival. Curr Oncol Rep (2017) 19(7):48. doi: 10.1007/s11912-017-0605-6

244. Matsuo K, Cahoon SS, Yoshihara K, Shida M, Kakuda M, Adachi S, et al. Association of Low-Dose Aspirin and Survival of Women With Endometrial Cancer. Obstet Gynecol (2016) 128(1):127-37. doi: 10.1097/AOG. 0000000000001491

245. Nordstrom T, Clements M, Karlsson R, Adolfsson J, Gronberg H. The Risk of Prostate Cancer for Men on Aspirin, Statin or Antidiabetic Medications. Eur J Cancer (2015) 51(6):725-33. doi: 10.1016/j.ejca.2015.02.003

246. Murray LJ, Cooper JA, Hughes CM, Powe DG, Cardwell CR. Post-Diagnostic Prescriptions for Low-Dose Aspirin and Breast Cancer-Specific Survival: A Nested Case-Control Study in a Breast Cancer Cohort From the UK Clinical Practice Research Datalink. Breast Cancer Res (2014) 16(2):R34. doi: $10.1186 / \mathrm{bcr} 3638$

247. Sanni OB, Mc MU, Cardwell CR, Sharp L, Murray LJ, Coleman HG. Commonly Used Medications and Endometrial Cancer Survival: A Population-Based Cohort Study. Br J Cancer (2017) 117(3):432-8. doi: 10.1038/bjc.2017.207

248. Irfan M, Kwon TH, Yun BS, Park NH, Rhee MH. Eisenia Bicyclis (Brown Alga) Modulates Platelet Function and Inhibits Thrombus Formation via Impaired P2Y12 Receptor Signaling Pathway. Phytomedicine (2018) 40:7987. doi: 10.1016/j.phymed.2018.01.003

249. Deng LP, Dong J, Cai H, Wang W. Cantharidin as an Antitumor Agent: A Retrospective Review. Curr Med Chem (2013) 20(2):159-66. doi: 10.2174/ 092986713804806711

250. Hsia CH, Lu WJ, Lin KH, Chou DS, Geraldine P, Jayakuma T, et al. Norcantharidin, a Clinical Used Chemotherapeutic Agent, Acts as a Powerful Inhibitor by Interfering With Fibrinogen-Integrin alphaIIb Beta3 Binding in Human Platelets. J Cell Mol Med (2018) 22(4):2142-52. doi: $10.1111 / \mathrm{jcmm} .13488$

251. Wojtukiewicz MZ, Hempel D, Sierko E, Tucker SC, Honn KV. Antiplatelet Agents for Cancer Treatment: A Real Perspective or Just an Echo From the Past? Cancer Metastasis Rev (2017) 36(2):305-29. doi: 10.1007/s10555-0179683-z

252. Hicks BM, Murray LJ, Hughes C, Cardwell CR. Clopidogrel Use and CancerSpecific Mortality: A Population-Based Cohort Study of Colorectal, Breast and Prostate Cancer Patients. Pharmacoepidemiol Drug Saf (2015) 24 (8):830-40. doi: 10.1002/pds.3807

253. Serebruany VL, Dinicolantonio JJ, Can MM, Goto S. Unclassified Pleomorphic and Spindle Cell Pulmonary Neoplasm With Brain Metastases After Prasugrel. Cardiology (2013) 124(2):85-90. doi: 10.1159/ 000346382

254. Smeda M, Kieronska A, Proniewski B, Jasztal A, Selmi A, Wandzel K, et al. Dual Antiplatelet Therapy With Clopidogrel and Aspirin Increases Mortality in 4T1 Metastatic Breast Cancer-Bearing Mice by Inducing Vascular Mimicry in Primary Tumour. Oncotarget (2018) 9(25):17810-24. doi: 10.18632/oncotarget.24891

255. Jayakumar T, Hsu CY, Khamrang T, Hsia CH, Hsia CW, Manubolu M, et al. Possible Molecular Targets of Novel Ruthenium Complexes in Antiplatelet Therapy. Int J Mol Sci (2018) 19(6):1818. doi: 10.3390/ijms19061818

256. Kelland L. The Resurgence of Platinum-Based Cancer Chemotherapy. Nat Rev Cancer (2007) 7(8):573-84. doi: 10.1038/nrc2167

257. Scolaro C, Bergamo A, Brescacin L, Delfino R, Cocchietto M, Laurenczy G, et al. In Vitro and In Vivo Evaluation of Ruthenium(II)-Arene PTA Complexes. J Med Chem (2005) 48(12):4161-71. doi: 10.1021/jm050015d

258. Jamieson ER, Lippard SJ. Structure, Recognition, and Processing of Cisplatin-DNA Adducts. Chem Rev (1999) 99(9):2467-98. doi: 10.1021/ cr980421n

259. Siddik ZH. Cisplatin: Mode of Cytotoxic Action and Molecular Basis of Resistance. Oncogene (2003) 22(47):7265-79. doi: 10.1038/sj.onc.1206933

260. Hsia CH, Jayakumar T, Sheu JR, Tsao SY, Velusamy M, Hsia CW, et al. Structure-Antiplatelet Activity Relationships of Novel Ruthenium (II) Complexes: Investigation of Its Molecular Targets. Molecules (2018) 23 (2):477. doi: 10.3390/molecules23020477

261. Khamrang T, Hung KC, Hsia CH, Hsieh CY, Velusamy M, Jayakumar T, et al. Antiplatelet Activity of a Newly Synthesized Novel Ruthenium (II): A
Potential Role for Akt/JNK Signaling. Int J Mol Sci (2017) 18(5):916. doi: $10.3390 / \mathrm{ijms} 18050916$

262. Hsia CH, Velusamy M, Sheu JR, Khamrang T, Jayakumar T, Lu WJ, et al. A Novel Ruthenium (II)-Derived Organometallic Compound, TQ-6, Potently Inhibits Platelet Aggregation: Ex Vivo and In Vivo Studies. Sci Rep (2017) 7 (1):9556. doi: 10.1038/s41598-017-09695-Z

263. Chen J, Zhang Y, Li G, Peng F, Jie X, She J, et al. Cytotoxicity In Vitro, Cellular Uptake, Localization and Apoptotic Mechanism Studies Induced by Ruthenium(II) Complex. J Biol Inorg Chem (2018) 23(2):261-75. doi: 10.1007/s00775-017-1528-2

264. Chlopicki S, Olszanecki R, Janiszewski M, Laurindo FR, Panz T, Miedzobrodzki J. Functional Role of NADPH Oxidase in Activation of Platelets. Antioxid Redox Signal (2004) 6(4):691-8. doi: 10.1089/ 1523086041361640

265. Akbar H, Duan X, Piatt R, Saleem S, Davis AK, Tandon NN, et al. Small Molecule Targeting the Rac1-NOX2 Interaction Prevents Collagen-Related Peptide and Thrombin-Induced Reactive Oxygen Species Generation and Platelet Activation. J Thromb Haemost (2018) 16(10):2083-96. doi: 10.1111/ jth. 14240

266. Lu Y, Hu Q, Jiang C, Gu Z. Platelet for Drug Delivery. Curr Opin Biotechnol (2018) 58:81-91. doi: 10.1016/j.copbio.2018.11.010

267. Jin S, Wang Y, Zhu H, Wang Y, Zhao S, Zhao M, et al. Nanosized AspirinArg-Gly-Asp-Val: Delivery of Aspirin to Thrombus by the Targetcarrier Arg-Gly-Asp-Val Tetrapeptide. ACS Nano (2013) 7(9):7664-73. doi: $10.1021 / \mathrm{nn} 402171 \mathrm{v}$

268. Chen X, Wang Q, Liu L, Sun T, Zhou W, Chen Q, et al. Double-Sided Effect of Tumor Microenvironment on Platelets Targeting Nanoparticles. Biomaterials (2018) 183:258-67. doi: 10.1016/j.biomaterials.2018.07.005

269. Li J, Ai Y, Wang L, Bu P, Sharkey CC, Wu Q, et al. Targeted Drug Delivery to Circulating Tumor Cells via Platelet Membrane-Functionalized Particles. Biomaterials (2016) 76:52-65. doi: 10.1016/j.biomaterials. 2015.10.046

270. Hu Q, Sun W, Qian C, Wang C, Bomba HN, Gu Z. Anticancer PlateletMimicking Nanovehicles. Adv Mater (2015) 27(44):7043-50. doi: 10.1002/ adma.201503323

271. Ye H, Wang K, Wang M, Liu R, Song H, Li N, et al. Sun: Bioinspired Nanoplatelets for Chemo-Photothermal Therapy of Breast Cancer Metastasis Inhibition. Biomaterials (2019) 206:1-12. doi: 10.1016/ j.biomaterials.2019.03.024

272. Xu P, Zuo H, Chen B, Wang R, Ahmed A, Hu Y, et al. Doxorubicin-Loaded Platelets as a Smart Drug Delivery System: An Improved Therapy for Lymphoma. Sci Rep (2017) 7:42632. doi: 10.1038/srep42632

273. Li YT, Nishikawa T, Kaneda Y. Platelet-Cytokine Complex Suppresses Tumour Growth by Exploiting Intratumoural Thrombin-Dependent Platelet Aggregation. Sci Rep (2016) 6:25077. doi: 10.1038/srep25077

274. Zhang X, Wang J, Chen Z, Hu Q, Wang C, Yan J, et al. Engineering PD-1Presenting Platelets for Cancer Immunotherapy. Nano Lett (2018) 18 (9):5716-25. doi: 10.1021/acs.nanolett.8b02321

275. Hu Q, Sun W, Wang J, Ruan H, Zhang X, Ye Y, et al. Conjugation of Haematopoietic Stem Cells and Platelets Decorated With Anti-PD-1 Antibodies Augments Anti-Leukaemia Efficacy. Nat Biomed Eng (2018) 2 (11):831-40. doi: 10.1038/s41551-018-0310-2

276. Han X, Li H, Zhou D, Chen Z, Gu Z. Local and Targeted Delivery of Immune Checkpoint Blockade Therapeutics. Acc Chem Res (2020) 53(11):2521-33. doi: 10.1021/acs.accounts.0c00339

277. Li H, Wang Z, Chen Z, Ci T, Chen G, Wen D, et al. Disrupting Tumour Vasculature and Recruitment of Apdl1-Loaded Platelets Control Tumour Metastasis. Nat Commun (2021) 12(1):2773. doi: 10.1038/s41467-02122674-3

278. Papa AL, Jiang A, Korin N, Chen MB, Langan ET, Waterhouse A, et al. Platelet Decoys Inhibit Thrombosis and Prevent Metastatic Tumor Formation in Preclinical Models. Sci Transl Med (2019) 11(479):eaau5898. doi: 10.1126/scitranslmed.aau5898

279. Hyslop SR, Josefsson EC. Undercover Agents: Targeting Tumours With Modified Platelets. Trends Cancer (2017) 3(3):235-46. doi: 10.1016/ j.trecan.2017.01.006

280. Smeda M, Przyborowski K, Stojak M, Chlopicki S. The Endothelial Barrier and Cancer Metastasis: Does the Protective Facet of Platelet Function 
Matter? Biochem Pharmacol (2020) 176:113886. doi: 10.1016/j.bcp. 2020.113886

281. Marriott G. Engineering Platelets for Tumour-Targeting. Aging (Albany NY) (2016) 8(8):1572-3. doi: 10.18632/aging.101014

282. Zhang X, Li X, Sun S, Wang P, Ma X, Hou R, et al. Anti-Tumor Metastasis via Platelet Inhibitor Combined With Photothermal Therapy Under Activatable Fluorescence/Magnetic Resonance Bimodal Imaging Guidance. ACS Appl Mater Interfaces (2021) 13(17):19679-94. doi: 10.1021/ acsami.1c02302

Conflict of Interest: The authors declare that the research was conducted in the absence of any commercial or financial relationships that could be construed as a potential conflict of interest.
Publisher's Note: All claims expressed in this article are solely those of the authors and do not necessarily represent those of their affiliated organizations, or those of the publisher, the editors and the reviewers. Any product that may be evaluated in this article, or claim that may be made by its manufacturer, is not guaranteed or endorsed by the publisher.

Copyright () 2021 Yu, Guo, Chang, Zhang, Zhang, Pei, Pang, Zhao and Chen. This is an open-access article distributed under the terms of the Creative Commons Attribution License (CC BY). The use, distribution or reproduction in other forums is permitted, provided the original author(s) and the copyright owner(s) are credited and that the original publication in this journal is cited, in accordance with accepted academic practice. No use, distribution or reproduction is permitted which does not comply with these terms. 